S B

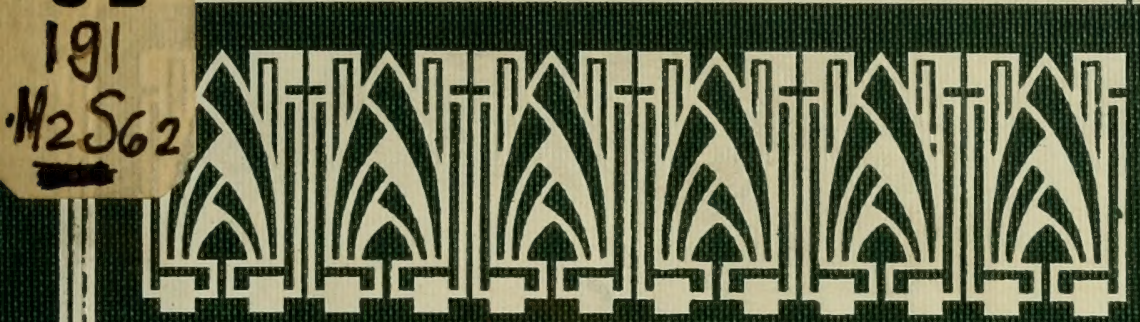

1

How to Grow 100 Bushels of Corn Per Acre on Worn Soil

"CORN IS KING"

WILLIAM C. SMITH OF IMDIANA 


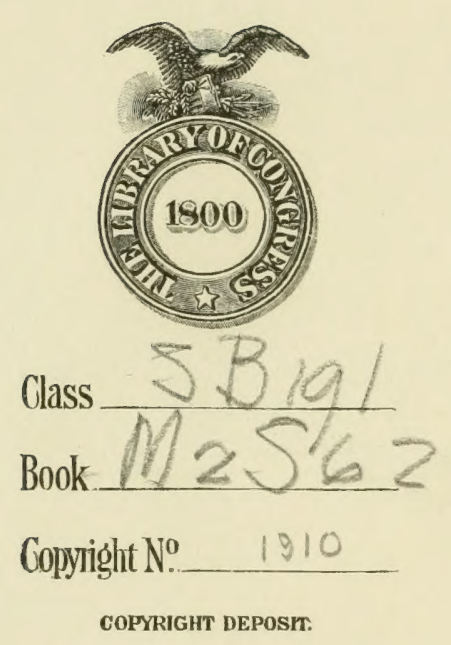










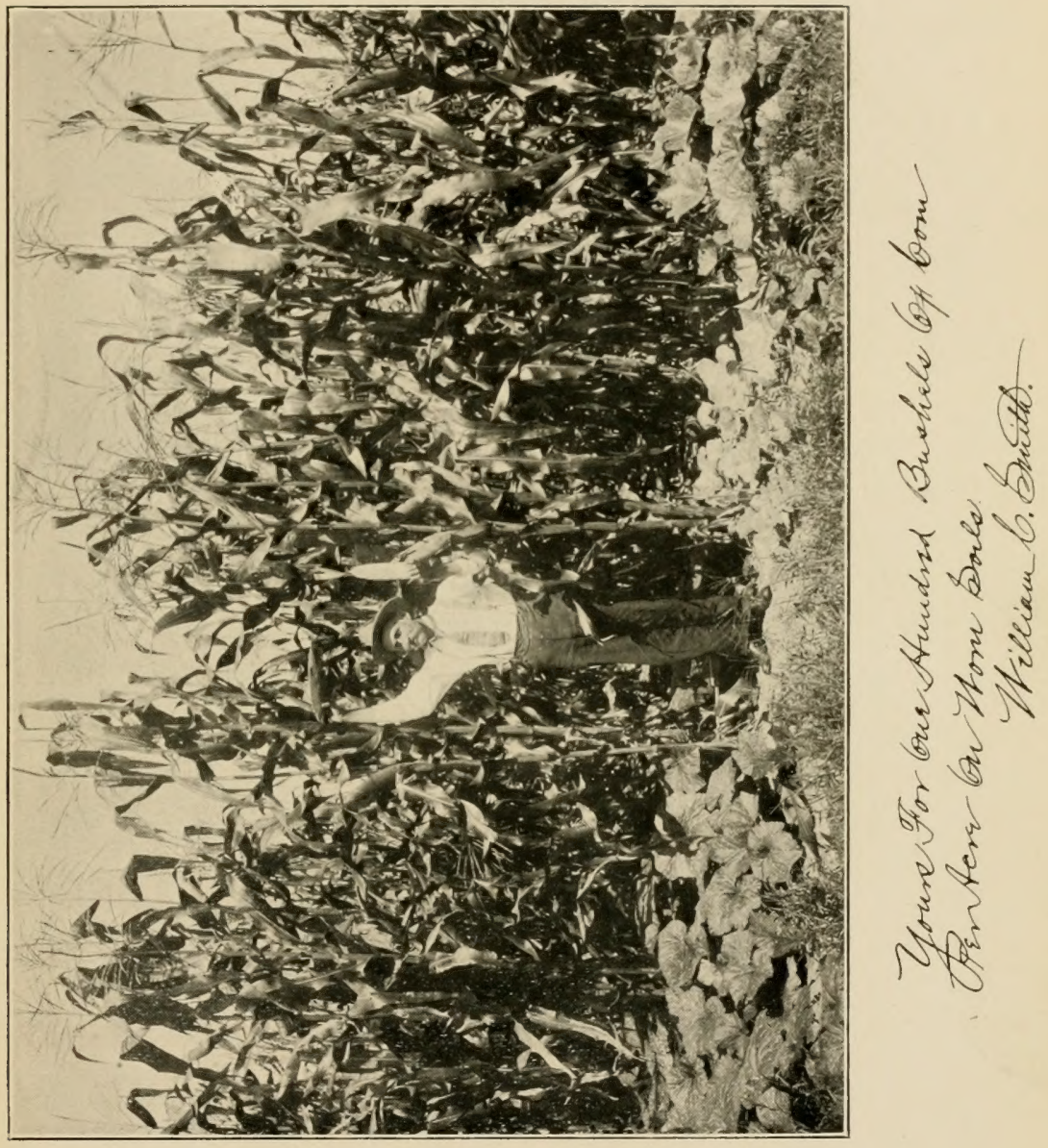





\title{
How to Grow
}

\section{One Hundred Bushels of Corn Per Acre On Worn Soils}

\section{"CORN IS KING"}

\author{
By \\ WILLIAM C. SMITH \\ OF INDIANA
}

ILLUSTRATED 
Copyright, 1910, by

William O. Smith.

All Rights Reserved.

C C. A25.9561 
THE FARMER OF THE PAST SCORNED THE STUDY OF SCIENTIFIC AGRICULTURE. HE FUUND THE SOIL RICH IN THE ELEMENTS THAT PRODUCED STOREHOUSES OF RICHES. HE TOLCHED IT WITH THE WAND OF GREED AND NEGLECT-IT WAS STRANGLED WITH ITS WASTED FERTILITY.

THE MODERN FARMER BECAME A STLDENT OF SCIENTIFIC AGRICULTURE. HE FOUND THE SOIL DEPLETED AND DESPOILED OF ITS FERTILITY. HE TOUCHED IT WITH THE WAND OF HIS KNOWLEDGE-IT BECAME RICH IN THE ELEMENTS THAT PRODUCE A HUNDREDFOLD.

There grows in Nature's Garden the plants with which the farmer can restore his sick, worn-out soils. These plants are the silent working forces of Nature that do their work better than any artificial agency devised by man.

It behooves us to study Nature's way of doing things.

"Accuse not Nature, she hath done her part. Do thou but thine."--Milton. 


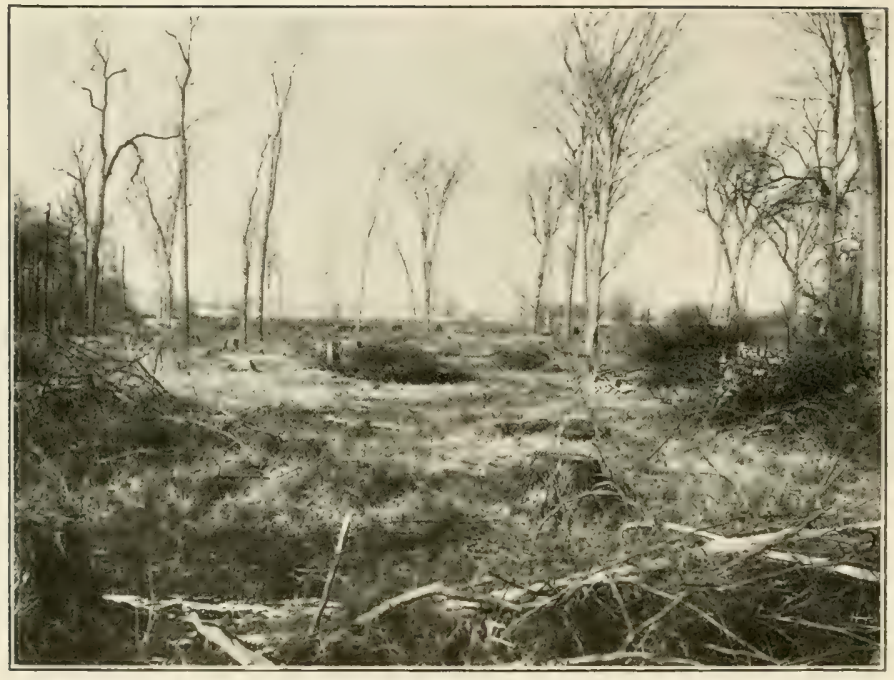

"The Clearin'." 


\section{PROEM.}

In a little frame farmhouse on a pioneer's farm, in the Indian Reserve, ont of which Hh, ward connty. Indiana. was carved, the author first saw the light of day. His first vision of the world was thromgh the six by six glass windows out across the door yard and public highway into the "clearin'." His father, a sturdy pioneer, had settled in this wilderness abounding in sigantic walnut. poplar and oak trees, interspersed with the smaller varieties of timber and underbrush, and by strength of muscle alone was subluing the forests and making the land to blossom with the fruits of the husbandman.

The pioneer father is slecping now. Ile sleeps beside the faithful wife who save him companionship in the days of his toil. Ile sleeps in the beantiful land made so by the strength, toil and endurance of the pioneer.

To the memory of that pioneer father, who loved the soil, this book is dedicated: and as the pioneer bathers subdued the land from the wilderness and gave it to their children, rich in the fertility that Nature gave it. may the children so farm and treat it that that fertility may increase and not decrease as the years go by.

The anthor loves the soil or else this book would have ne'er been born.

Loving the soil as he does, his indignation is aroused when he sees it despoiled by the soil robber. If this book will only awaken the conscience of the soil despoiler, the author will feel that his efforts have not been in vain.

$$
\text { WILLIAM C. SMITII. }
$$

Delphi, Indiana, January, ıэго. 


\section{INTRODUCTION.}

Abandoned farms and decreasing production of our farm lands is the present-day menace of our country. Increasing population, decreasing fertility of our soils and fewer acres of new land opened for settlement brings us each day nearer the solution of the problem, how shall we feed our people?

The answer to the question is the "Renovation of Morn-out Soils" so that they will ayain produce as they did when our forefathers subdued them from the wilderness that held them in subjection for centuries.

Renovation of the Soil-what does it mean?

It means to make the soil over again, to restore it to freshness or vigor-to renew it.

Too many American farmers have gone upon the principle that their land will never wear out. Their fathers entered upon land covered with the virgin forest, rich in all the elements that make good soil; the forests were subdued and the land brought into cultivation; bountiful 
crops were produced hecanse the soil was well supplied with humus, nitrogen, potash and other elements found in first-class soils. Year after year bumper (rops were gathered from these lands, the pioneer died, and his sons and son's sons continued to farm these lands in the same manner and with the same methods as they were famed by the pioneer.

It did not seem possible to the sons and son's sons that these rich lands could ever reach the point of exhaustion or that the time would come when they must be farmed and treated in a different manner than when they were first cleared and planted, get that very time has come to millions of acres of American soils.

Millons of acres of onr land that once produced from seventy-five to ane hundred bushels of corn per acre will not now produce twenty bushels to the acre. These acres have gone into "agricultural bankruptcy."

Being confronted with this condition, what can we do to remedy it? Is there a remedy and is the remedy a sure and quick one? The remedy must be quick, for we cannot wait fifty years as Fneland did to restore onr soils.

The purpose of this book is to give the remerly and to prove that it is a sure and quick one. 



\section{TABLE OF CONTENTS.}

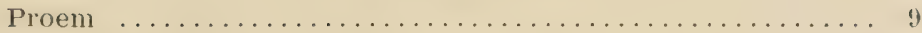

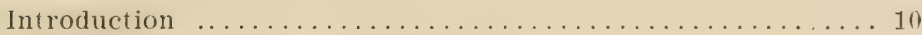

CHAPTER I.

Soil

CHAPTER II.

Drainage

CHAPTER III.

Organic Matter.

CHAPTER IV.

Soil Ventilation.

CHAPTER V.

Plowing

CHAPTER VI.

Soil Covering.

CHAPTER VII.

How to Get Organic Matter Into the Soil, Rye.......... 45

CHAPTER VIII.

Hungarian 51

CHAPTER IX.

Sand, Winter or Hairy Vetch. 5.)

CHAPTER $\mathrm{X}$.

Vetch and Alfalfa

CHAPTER XI.

My Methods of Restoring Worn and Worn-Out Soils 73

CHAPTER XII.

King Corn $\pi$

CHAPTER XIII.

The Culture of Corn

CHAPTER XIV.

Sweet Corn. 93

CHAPTER XV.

A Chapter of Don't Forgets. 101

CHAPTER XVI.

Conclusion 109 



\section{LIST OF ILLUSTRATIONS}

Frontispiece.

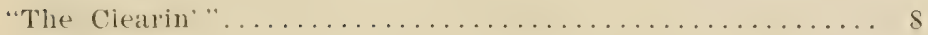

The Original Soil Builders in the Timber Belt......... 16

Nature's Plows and Cultivators at Winter Rest......... 36

A Young Vetch Plant Showing Nitrogen . Vodules on Its Roots. 44

Vetch Plant Taken From Frozen Soil................ it

A Bunch of Vetch Taken From Under Ice and Water...... 58

Vetch Plants Taken in 11 inter From High Sand Ridge...... 6:2

Vetch Seed, Actual Size...................... gs

Vetch Seed, IIagnified....................

A Promising Field of Corn, Fertilized With Vetch........ 76

A Promising Potato Field, Fertilized With Vetch........ 86

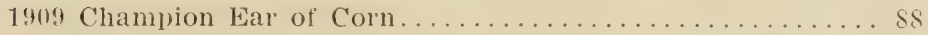

1909 Champion Ears of Corn...................... 91

A Good Type of Sweet Corn Seed, Stowell's Evergreen..... 99

The Farmer's Best Product if $-\ldots \ldots \ldots \ldots \ldots \ldots \ldots \ldots$. $10 \mathrm{~s}$ 


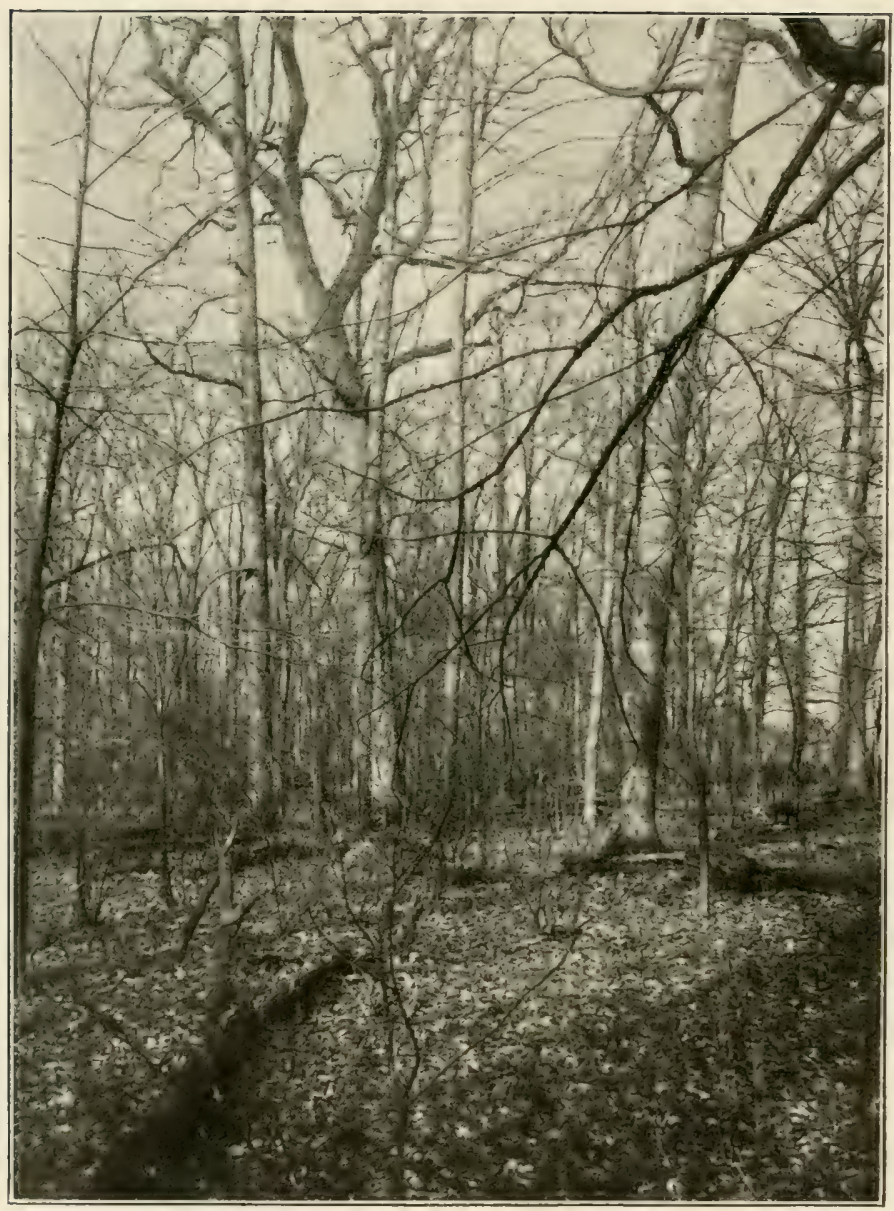

The Original Soil Builders in the Timber Belt. 


\section{CHAPTER I.}

\section{Soil.}

Soil is defined as being the upper stratum of the earth or that compound substance which furnishes nutriment to plants or which is particularly adapted to support and nourish them.

Soil varies in depth from a few inches to several feet. Clay soils were produced by the wearing down and decomposition in part, of rocks containing aluminous minerals, as granite. Sandy soil consists of fine particles of stone placed where found, by the washing of water. Nuck soil is produced loy the decay of large quantities of vegetation.

Clay and sandy soils were originally improved and made rich by the addition for centuries of regetable matter such as leaves, weeds and other vegetation.

We agree with him who said "that the condition of the suil is of more importance than its character." Any kind of soil, whether clay, sandy or muck, can be made to produce large crops if put in proper condition.

While it is true that clay or heavy soils have more of the elements of plant growth in them, yet sandy or muck soils by proper treatment will produce as much, if not more, than the clay or heavy soils.

In life's battles the "knowing how" is the entering wedge that opens the way to success. So it is in the treatment of the soils, the "knowing how" to put them in condition is the secret of success in growing crops. 


\section{SOIL}

It is appalling in going over the country to see so many farmers so treating their lands as to bring them each day nearer the doom that hangs over all mistreated lands. "the abandoned farm."

Not one farmer in ten is giving his land a chance. Not one in ten seems to know how to build up his soil, or if he does, he seems to be going on the principle that he can gret enough from his land to support him during his lifetime and does not care for his posterity or future generations.

He is like an ex-governor of a great state who spent his declining days on the farm which before he died was in the worst condition of any in the neighborhood. l'eople wondered why a man whose life and business in other lines had been so suceessful should allow his farm. upon which he was residing, to get in such condition. The governor was interrogated resarding the matter and replied, "I am not farming for future generations."

lint it is encouraging to see so many of our great financiers, statesmen and people in the humbler walks of life becomins interested in soil restoration. ()ur asricultural schools are doing a noble work along this line.

If it be true that the condition of the soil is of more importance than its character, then it is not necessary for us to go into the discussion of the relative value of the different kinds of soils, further than to say that some of the extreme sandy soils of New Jersey and Long Island have by proper treatment been transformed into the richest of soils; so have the sandy lands of Holland been made worth $\$ 3,000$ per acre by proper treatment.

After thorough study, backed up by actual experiment, we make the statement that most any sandy or clay soil can be made to yield Ioo bushels of corn per acre.

That this can be done, and done quickly, we have demonstrated by actual experiments.

Three elements are necessary to make good soilspotash, phosphorous and nitrogen-and the last men- 


\section{SOIL}

tioned, according to the best authority, is the "most precious, the most important and the most costly."

It is said that "nitrogen promotes growth, phosphorous produces frutfulness and early maturity, and potash increases quality."

Most sandy, clay or heary soils contain sufficient petash and phosphorous, but are wholly lacking in humus and nitrogen.

One writer says that "corm, oats and wheat are made of plant ford: that they consist of ten certain elementary substances; that a ton of corn contains a ton of these plant foud elements, of which only three are secured by the corn plant from air and water. The seven are taken from the soil. The three elements make up more than ninety per cent of the corn, but the other seven are no less essential to plant growth."

The seren elements mentioned and which make up but ten per cent of the corn crop, are generally found in sufficient quantities in all soils to last from 500 to 17.600 years.

The chief lack of worn-out soils is humus and nitrogen.

Soils originally procured their supply of humus and nitrogen from decayed vegetation secured in their progress of formation.

Go into the virgin forest such as once covered the middle west, and there are some such forests existing today, but they are not large, and you will see between the trees the gromnd covered with decayed and decaying tree trunks and limbs and a heavy coating of leaves.

This decaying of trees and leaves has been going on for hundreds of years, thus storing up a vast storehonse of the precions elements of rich soil. Is it any wonder then that lands when first cleared of the virgin forest irere so rich?

Continued cultivation of cleared lands withont the addition of anything to reproduce these original elements has exhausted these elements from our soil, and until we can 
get them back into the soil again, our lands lacking in these elements will become more worthless as the years go by.

When we consider that it took centuries to put large quantities of nitrogen and humus into our soils, it seems an impossible task to get back into these soils again within a short time the quantities of nitrogen and humus that took so long to put there in the first instance.

Barnyard manure will put these elements back into the soil quicker than any other known agency, but this remedy is impracticable to use on a large scale because sufficient quantities of manure cannot be obtained.

Commercial fertilizer will not do the work for the chief reason that they do not contain the humus, and for the further reason that the mineral matter in the soil is sufficiently dissolved by coming in contact with water and moisture to furnish the needs of plant yrowth. This dissolution is continued in sufficient amounts to keep up the necessary supply of minerals, and so the adding of commercial fertilizers will not, as a rule, add to the supply of plant food in the soil.

It is said that there is enough nitrogen in the air over an acre of ground to grow 75 bushels of corn per acre per year for (noo,0oo years, but the nitrogen is of no value to the soil muless it is drawn into it from the air, so that the plant in the soil can assimilate it into its system and thus secure the element that makes vigor of growth.

But soils need humus as well as nitrogen.

We are hearing much of the "Volusia soils," so named from a village in New York where first noticed.

A writer speaking of these soils says: "They are worn and inproductive, extend from the Hudson river westward across the state through Pennsylvania into Ohio. Ten million acres, most part too poor to grow clover without fertilizers, are unfit for cultivation. They once produced goud crops: fine old houses and barns occupy them, which are now unoccupied. These lands dressed 
with liberal (fuantities of stable manure produce wood crops. It is said that if these soils are draine(l, supplied with or sanic matter and their acidity corrected so that bacteria can thrive in them, they become asain proluctive. In fine, these soils need drainage, organic matter in the form of manure, green crops plowed under and application of lime. It is said that these lands cannot get manure because they will not support stock."

Are not millions of acres of our soil in other great states of the Lnion becoming Volusiaimed? Ind is not the secret of their restoration contained in the application to them of drainage and organic matter? 



\section{CHAPTER II.}

\section{Drainage.}

No soil can be put in good tilth without thorough drainage.

As well try to grow most crops with "wet feet" as to attempt to grow them on hot desert soils. In both instances they will die. because they are ont of their proper environment.

Moisture you must have to grow crops. but moisture over-done, un-does.

It is as necessary for plant roots to breathe as human beings; shut off soil rentilation and you shut off free. oxygen from reaching the plant roots, and the plant dies.

There can be no soil ventilation when the soil is cold, compact and saturated with water. Hence the importance of drainage, and thorough drainage.

Drainage is of more importance to worn-out soils than it is to new soils. New soils are porous and water will easily percolate through them.

Worn-out soils are hard, compact and non-porous. They are almost absolutely incapable of affording rentilation to plant roots.

Drainage is one of the most effective methods of getting this needful soil ventilation.

The more drainage in worn-out soils the better; no matter whether water is on the land or not, put into them as much ditching as you can. There is no danger of getting too many drains. 


\section{DRAINAGE}

Ditches give the proper temperature to the soil, promotes soil ventilation and conserves soil moisture.

Most heavy soils are compact and cold, the temperature in them is too low, and the soil ventilation too inadequate to be conducive to plant growth. There is no room in them for plant roots to perform their proper functions.

Lands improperly drained are slow in drying out, and seeding in them is delayed beyond the proper season for planting, thus giving a shorter growing season.

It takes more labor to till cold, compact, non-drained soils. All kinds of soils are benefited by drainage.

The greatest advantage to be obtained by plenty of drainage is the putting of the sroil in that condition of porosity, deepness and pulverization as will prevent droughts as well as floods.

In a thoroughly ditched soil, plant roots at once strike deep where they are safe from the onsets of the summer droughts.

The experience of years has been that well-drained soils produce better crops in wet or dry seasons than the undrained soils, and experience has also shown that worn soils cannot be reclaimed until they are first well ditched.

In the light of this experience, I cannot too strongly impress upun my readers that we must first thoroughly drain our soils if we would build them up to a fertile stage.

All drains should be so constructed as to be open at both ends, as a drain so constructed will act like a chimney; the air will go into one end and out the other, and the air thus passing through the drain in dry weather is condensed into moisture, which is thrown out into the soil, made porous by drain construction, and thus furnishes moisture to the plant roots.

The source of all drains should terminate in some fence row close to the fence, the tile brought up to the 


\section{DRAINAGE}

surface of the ground and properly screened to prevent animals, weeds, sticks or foreign substances from entering the drain.

The mouth of drains should be kept (ipen at all times and screened in the same manner. Such a ditch is the most valuable asset on the farm.

Drains should be constructed of not less than six-inch tile. and need not ordinarily exceed four feet in depth. but no fixed rule as to depth of drain can be given, as the molulating character of the soil and the untlet must govern the depth. Where lands are too deeply tiled there is likely to be a waste of water.

In constructing drains, the idea of soil ventilation must be kept in mind, so it does not matter in all cases whether a drain will carry water or not; it is useful if it only affords ventilation, provided both ends of the drain are open. 



\section{CHAPTER III.}

\section{Organic Matter.}

It is of great importance to crop production that organic matter be in the soil.

I have shown why newly cleared soils were so rich in fertility-they are rich in organic matter.

Good authorities say that humus in the soil absorlos three times as much water as its weight in clay, and retains it twice as long. and five times as much as sand and retains it five times as long.

There is no danger of getting too much humus into the soil. An acre of land twelve inches deep weighs 2,000 tons. It would take roo toms of organic matter plowed under every two or three years to make one-twentieth part of the 2,000 tons.

For a soil to be in its highest stage of fertility it must contain germ life and bacteria. These are always found in their greater abundance within the first six inches of soil, and they get their food from organic matter.

As they cannot get any feeding matter from the minerals of the soil, they cannot exist in any soil lacking in organic matter.

In virgin soils they are found in abundance, where they reach their highest stage of development.

This germ life and bacteria in the soil play an important part in preparing the soil, or putting it in the proper condition for plant growth.

They are the little constant workers in Nature's labor- 
atory, that compound and distribute the substances needed for plant food. They cleanse the suil of its offensive acctmulations and are one of the best aids to successful agriculture.

It has been said that land without organic matter is but the skeleton of the soil, and that the organic matter makes the flesh.

The system of farming in vogue in the Lnited States for the past one hundred years has farmed out of the soil most all the organic matter originally in them. It has. stripped the body of its flesh and nothing but the skeleton remains.

For instance, the average farmer will one year plant a field in corn. The next season he will break, rake and burn every stalk and put it in corn again. In the fall he will sow wheat in the corn. The next season he will break the ground and put in wheat again: perhaps he will sow clover in the wheat in the spring. If the clover is a good stand, the next season he will remove from the field not only the first clover crop but also the seed crop, and the following spring break up for corn again, and continue on and on this same process.

This is regarded good farming. They tell us it is crop rotation, and builds up out farms. Yet I say to you, that under this very system our farms have grown and are growing poorer every year. That the organic matter in the soil is becoming less and less, and why? Because not sufficient organic matter is being adcled to the soil to keep up the necessary supply.

The corn stalks were in the majority of cases burned and destroyed; the wheat stubble with its roots was insignificant. Both crops of clover were removed, leaving nothing but the stubble and roots, which are insignificant.

In all these years more organic matter was removed than added to the soil, and the supply of humus was gradually being exhausted. 
What about the fields that have been planted each year to corn for ten, fifteen, twenty and even seventy years, and stalks removed and burned each year: And what about the many fields rotated with corn, wats and wheat only, and the stalks and stubl)les in most cases burned?

Vegetable matter destroyed by burning resolves into air from 90 to 99 per cent of its organic parts.

If this be true, then the value of the ashes obtained from burning vegetation is too small to be considered.

Standing in the receding twilight of an April erening. I have seen the entire visible horizon of the famous Wabash Valley aglow with the reflection from the fires of burning corn stalks, raked up into windrows, from thotwands of acres of soil, that needed the humus, potash and nitrugen abounding in these stalks, but which was going up in smoke, to be lost forever to these acres of soil that are fast losing their fertility. Is I looked upon this thoughtless and almost criminal destruction of soil fertility, I saw in my imagination pictured in the reflected light upon the sky, pictures of "Agricultural I'ankruptey" and "Abandoned Farms." and as I beheld this pictured doom of the American farm, I exclaimed: When, oh when, will the American farmer come into a realization of this awful destruction of soil wealth?

One day in the spring of I9o9, while directing some work on my farm, I noticed to the north great clouds of smoke and flame covering a large area. I wondered what could be burning. The conflagration was too large for burning corn stallis or buildings. Later in the day I learned that a farmer (?) had touched a match to a forty-acre field of dry lig English clover grown on the ground the previous season and left uncut.

When I learned of this conscienceless destruction of soil fertility, I said in my wrath: The match in the hands of the American farmer is a menace to the farm.

In the growing of this clover and leaving it uncut to 
cover the ground through the leaching season of fall, winter and spring, this farmer had taken the first and an important lesson in soil restoration. But his second and best lesson was left mlearned.

Think what it would have meant to that soil and that farmer had that splendid crop of organic matter, so full of the precious soil elements, nitrogen and humus, been turned under by the plow.

Think how the little rootlets of the corn would have reveled in this mass of organic matter, mixed with the soil and drawing from it into the corn system those elements that make that sturdiness of wrowth that produces a heavy paying crop on the farm.

Again, think of the financial loss to that farmer from the destruction of the clover. For it has been estimated that the potash, phosphoric acid and nitrogen in a ton of clover hay is worth \$I7.57 for manure. There was not less than a ton of clover hay on each acre of the forty-acre field, worth a total of \$702.80 plowed under for manure.

The farmer's only excuse for burning was that the clover was so heavy that it could not be plowed under. This we dispute. The right kind of a double-disc plow would have turned it under nicely. Of course the plow would have occasionally choked up, and it would have taken longer to plow the field, but it would have been well worth the time and extra labor, for the farmer would have secured for this field a fertility that would have yielded him large returns.

The same excuse that this farmer made for burning the clover, is made for burning corn stalks; that is, they cannot be plowed under so as not to interfere with the cultivation of corn and other crops. This we also dispute. We have turned under the rankest kind of growth of corn stalks that never were pastured, with an ordinary walking plow and log chain. Of course, some stalks were left sticking out of the ground and in the cultiva- 
tion of crops an occasional hill of corn was jerked out of the ground by the cultivator catching on the stalks insufficiently plowed under, but what of that? The loss of a few hills of corn is nothing compared to the great loss of the stalks if destroyed by burning.

In instance is given of two farmers owning farms side by side, one of whom always gathered up his corn stalks and burned them. The other never allowed a stalk or a straw to be burned on his land. After fifteen years the former farmers farm vielded fifteen bushels wi corn less to the acre than when he first commenced farming it, while the latter's farm produced as well as it did at the beginning of the fifteen years.

One hundred bushels of corn contains about IOO pounds of nitrogen, I 7 pounds of phosphorous and 19 pounds of potassium.

The stalks upon which the Ioo bushels of corn grew contain about to pounds of nitrogen, o pounds of phosphorous and 52 pounds of potasium. All these elements in the stalks have a money value of \$II.O4.

These elements in the corn itself are lost to the soil if the corn be sold, but that in the stalks can be saved to the soil if the stalks are not burned lout are plowed under.

In the black prairies of Illinois and Lowa and the rich river bottom lands of Indiana are vast acres of land that used to produce an arerage crop of sixty or more bushels of corn to the acre. The average is now less than forty bushels to the acre.

The virgin richness of these lands conld have been continued simply by the plowing under of the corn stalks grown on them.

The American farmer must learn the lesson of getting organic matter into his soil or his farm is doomed.

Nature understood her business when she covered our lands with forests and the vast prairies with large growing grasses, so that the decay of tree trunks, limbs, leaves and grasses would intermingle with the sand and 
the clay and thus produce the rich lands for the farmer. but the farmer has not learned the lesson that when he gets away from Nature's ways of soil building he is heading towards the doom of soil exhaustion.

We are so apt to do things as our fathers did, forgetting that onr fathers lived under different environments than we do.

The pioneer farmer had the soil in its original freshness and had no need of building it up. It was rich enough. The children were by this pioneer, who was not bound by any necessity of a change of farming methods, taught the simple lesson of farming just as he did.

But when the land fell into the inheritance of the children's children it had almost reached the point of soil exhanstion, and the children's children being lound with the cords of enviromment. lacked stifficient will or mental power to break them, and kept on farming as their fathers did, thus showing the great strength and influence of environment.

It is said that in the magic transformation of dirt on the farm into dollars no one is robbed. True-if the one who touches the soil with the magic wand is not a soil robber. But the wand in the hands of a soil robber plunders all mankind alike, and as some one has said in thought, Nother Earth, resenting the infamy heaped upon her and her people, bears the pain in silence but inflicts the awful punishment that falls on all alike, by withdrawing her bounty. 


\section{CHAPTER IV.}

\section{Soil Ventilation.}

I have said something of soil ventilation and that plants cannot thrive without it. I have also said that plant roots must breathe or the plant will die.

If soil is so compact that air cannot enter it, the plant is injured as much as if it had no water.

Entirely exclude oxygen from seeds placed in the soil and you get no growth. If you have some ventilation but not enough, then you have the sickly plant. It is said that "a plant lacking in root breathing is drowned as effectively as an animal would be under water, becanse enough free oxygen cannot reach them." Insufficient ventilation resulting from poor drainage destroys organic matter in the soil.

Sufficient soil ventilation produces the necessary nitrates in the soil and prevents their destruction as well.

Air must penetrate deeply into the soil, and the passage of the air must be both in and out of the soil.

Soils underlaid with coarse gravel, sandy and light soils, are generally strong on ventilation, while compact clay and heavy soils are short on ventilation.

Soil is said to be a living thing. But it is only alive when it is full of organic matter and porous veins, so that it can breathe from the air the gases needed by the plant root.

Tuberculosis enters our insufficiently ventilated homes 
and soil exhaustion enters upon the compact non-porous soils.

We must ventilate our homes if we live, and this is as applicable to the soil as it is to man.

Soil rentilation can be secured by drainage, deep tillage and plowing in, of course, organic matter. Certain plants, like the alfalfa plant, penetrate their roots deep into the soil and when they decay leave openings into which air finds its way. Next to drainage, soil ventilation is best secured by the plowing under of heary crops of organic matter, such as corn stalks, rye, vetch, buckwheat, hungarian and clover.

It must not be forgotten that a soil filled with water cannot possibly breathe, neither can a close, compact soil, so a soil may be fairly well drained and yet not be properly ventilated; hence the need of orsanic matter to aid in soil ventilation.

The necessity for soil ventilation is not only that oxygen may come in contact with the plant roots, but that a proper home may be established in the soil for the vast multitude of bacteria, so that they can perform their work of changing the nitrogen of decaying organic matter into a form suitable for plant food.

It seems that bacteria in the soil are affected by environment as well as man, so conditions of the soil will influence and modify their growth.

Soil bacteria being essential to a good. living. working soil, then we can see the need of effective soil ventilation so that the soil may be put in that condition that these bacteria may best develop and flourish.

TThen soil is in such condition it can be truthfully said that it is indeed a living thing and is only in the proper condition to give its best service in growing crops for the farmer. 



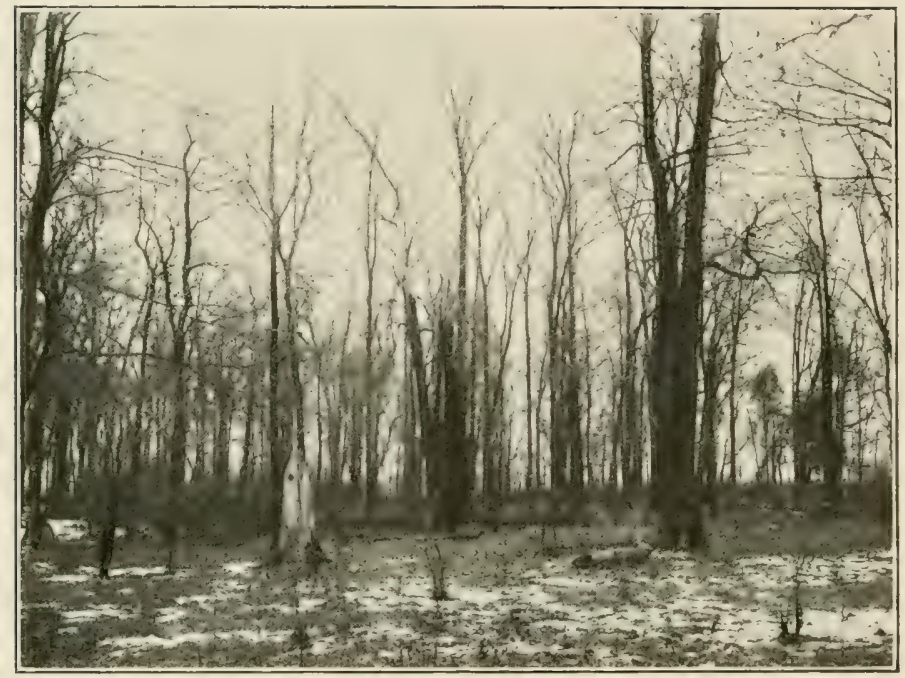

\section{Nature's Plows and Cultivators at Winter Rest.}

In the spring and growing seasons of the year if we could see into the soil covered with the forests, we would see the roots of trees shooting out and down into the soil as animated beings, and as they grow in size, we would see the soil loosened u) by their action and the pushing this way and that way of the roots and rootlets stir the soil more effectively than if stirled by the plow. 


\section{CHAPTER V.}

\section{Plowing.}

That proper plowing is one of the most important steps in soil building is apparent on close study.

That suil is improved by stirring is a truth only denied by the ignorant and tunobserving man. It is one of Nature's ways of aiding in soil building. The plows and cultivators of Nature are the roots of trees and plants.

In the spring and sowing seasons of the year, if one cottld see into the soil covered with the forests and regetation, he would see the roots shooting out and down into the soil as animated beings, and as they grow in size he would see the soil loosened up by their action. and the pushing this way and that way of the roots and rootlets stirs the soil more effectively than if stirred by the plow.

This observation of one of Nature's ways shows the importance of soil stirring.

I claim that soil should be stirred frequently. If it were possible to break up soils several times a year, their fertility would be increased.

It is one of Nature's ways to be busy. She is never idle. Nature will not allow soil to be idle, except in the winter season.

If soil is not occupied with growing crops, then Nature starts the weeds and grasses to occupy and cover the soil, and from this an important lesson is to be learned in successful soil cultivation. Keep your soil occupied 


\section{PLOWING}

with some useful crop. It takes as much plant food to grow weeds as to grow corn. Then why not plow or stir our ground after a crop is removed and plant to some crop of fertilizing value, and secure the great benefits of weed eradication, soil stirring, organic and fertilizing matter.

It is said that "tillage is a manure," that "frequent tillage is our best and cheapest manure," that "tillage and manure are one and the same thing."

I'lowing and stirring the soil mixes the organic matter with the minerals in the soil, affords better ventilation. gives the soil better ability to store up and deliver moisture to the growing crops, and gives more room for the plant roots to perform their proper functions.

There is a time to plow and a right and a wrong way to plow.

The plowing or stirring of ground, no matter what its character, when too wet is a crime against Nature's laws. and punishment follows, quick and sure.

The passing of the plow through the soil presses the soil grains together until the soil turned over becomes dense and impervious to water or plant roots. The soil thus turned over becomes like unburnt bricks dried in the sun, and ventilation is completely shut off. Its usefulness as a home for plant roots is destroyed.

And even if the surface soil be sufficiently dry but the sub-soil too wet, the passing of the plow through the soil will press the soil together mnder the plow and we get a compact stratum of earth below the top soil which will hold water above it and prevent moisture rising when needed.

All this shows the importance of plowing at the right time and with the right kind of plow.

There has been great evolution in breaking plows; we have many kinds and makes. The writer has tested all kinds and is convinced that the double-disc plow is the best of all. 


\section{PLOIVING}

A disc plow will plow soil that no other plow will. It is the only plow that will successfully turn under corn stalks and heavy masses of organic matter.

It pulverizes the soil as it turns it over, which no other plow will do, and its draft is lighter.

I have plowed with a disc plow in the fall of the year, black gumbo soil so hard that a steel walking plow could not be made to enter into it, and I have with a dise plow turned under weeds higher than the horses' backs so nicely that a single weed conld not be seen in the field. And with it I once turned under a field of hairy vetch, heary in foliage, after having tried all other kinds of plows and failed to make them do the work. I once plowed a strip fifty feet in width around a ten-acre field and then finished breaking the balance of the field with walking plows. The field was planted in corn, and during the entire season the corn on the strip plowed with the disc plow was more thrifty than the rest of the field and at least a foot higher.

I have never solved to my satisfaction the problem as to the proper depth to plow. In examining authorities and interviewing farmers, I find the opinions of men so varied on the subject that no reliable rule can be given which would be a safe guide in all cases.

In my own case, I have always aimed to plow to an average depth of six inches, all soils not covered too heavily with orsanic matter or green crops. In plowing under green crops, corn stalks, weeds, etc., I have regulated the depth according to the mass of organic matter to be plowed under.

I do not believe that deep plowing should ever be practiced in the spring. but I have known deep fall plowing: to be successful.

I believe it was Poor Richard who said:

"Plow deep while sluggards sleep,

And you shall have corn to sell and keep."

lint I fancy Poor Richard was simply writing poetry. 


\section{PLOIVING}

Poetic license, you know, allows one to measure thought in verse although the truth sought to be conveyed be far-fetched.

Drain well your soils, plant in them crops for green manures that send their roots deep down into the soil, then it will only be necessary to plow your soils deep enough to well cover the organic matter plowed under.

Tull, an agricultural writer, claims that by thoroughly pulverizing the soil its fertility can be permanently maintained; that by repeated plowing he produced twelve successive large crops of wheat on the same land without manure.

Supplement Tull's system of frequent plowing and pulverizing the soil with the turning under of plenty of organic matter and you have the secret of building and keeping up the fertility of the soil. 


\section{CHAPTER VI.}

\section{Soil Covering.}

Too much stress cammot be laid upon the importance of deing that to your soil that will keep it covered during the season of fall, winter and spring. which is known as the leaching season.

Terrific is the destruction each year to soil by leaching. Stand by our streams and rivers during their flondtide and see the thick comsistency of their waters made so by the heavy rains that fall upon the soil, mixing and dissolving its particles of dust and litter.

Hillsides and valleys are swept of their soil by the rapid washing of the waters, which, as stated, occurs more frequently in the rainy season.

Soils covered by, and filled with, close-lying herbage and thickly-rooted plants will not wash or wear away under the action of falling water, neither will such covered or root-filled soils be blown away by the winds.

If an estimate could be made of the soil wealth carried away each year by the waters falling from the clouds and washing away over ontr fields into our streams and rivers to the sea, and by the blowing of the winds, it would be appalling.

The remedy to check and preserve this flow of soil wealth to the sea, is keeping our soil, when not occupied by growing crops, covered as much as possible with the herbage and root-producing plants of rye, vetch, etc.

Covering the soils with these crops prevents puddling 


\section{SOIL COVERING}

of the soil. The growing and decaying of the roots aids in depositing the minerals and in bringing about the changes characteristic of new soils.

The open, mellow texture of the soil is produced by covering.

Naked, clayey soils, subjected to excessive rains, followed by drying winds and rapid water evaporation, forces them to crack open and their texture is thus injured. If such soils are covered, they are not subject to this process.

It has been observed that when soil is covered with any kind of close material for any length of time, it is so enriched that one would think manure had been applied to it. Even snow lying on the soil for months enriches it.

I have already shown that the reason virgin soil was so rich was on account of the ages of covering Nature gave it.

The secret of soil covering in promoting soil fertility lies in the fact that covered soil prevents ammonia wastes from the soil by evaporation, and the loss of nitrogen.

To preserve soil fertility, it must be kept covered as much as possible, yet the system of farming mostly in vogue in America is to strip the ground of every vestige of matter, expose it to the heat of the sun and the washing of rains.

Soil covering is an important lesson we American farmers must learn.

If after our fields of corn were laid by we would sow them in rye or vetch, and when corn is harvested roll down the stalks, all to be covered with the snows of winter, and no stock allowed to pasture upon them, what a wealth of fertility would be gathered under this covering during the leaching season.

What a mass of rich material to be plowed under to mix with the fertility produced by the covering during the season of rest. 


\section{SOIL COVERING}

But how does the average American farmer treat his cornfields? They are laid by without any green crop planted, the corn is gathered and then his herds of cattle and horses turned into them; and the fields are stripped of their precious coat of organic matter, the soil is ruined by the tramping. puddling and exposure to washing rains and baking sun.

The only exception is when corn is followed by wheat. and then too often the fields are pastured to their great injury. If a farmer has a stack of straw, he will either burn it or sell it, instead of spreading it on his soil, which would bring him more money value than the few dollars he gets for it, and if he burns it he has ganed nothing.

I wish I could burn it into every American farmer, that he must cover his swil if he womld keep up or increase its fertility. 


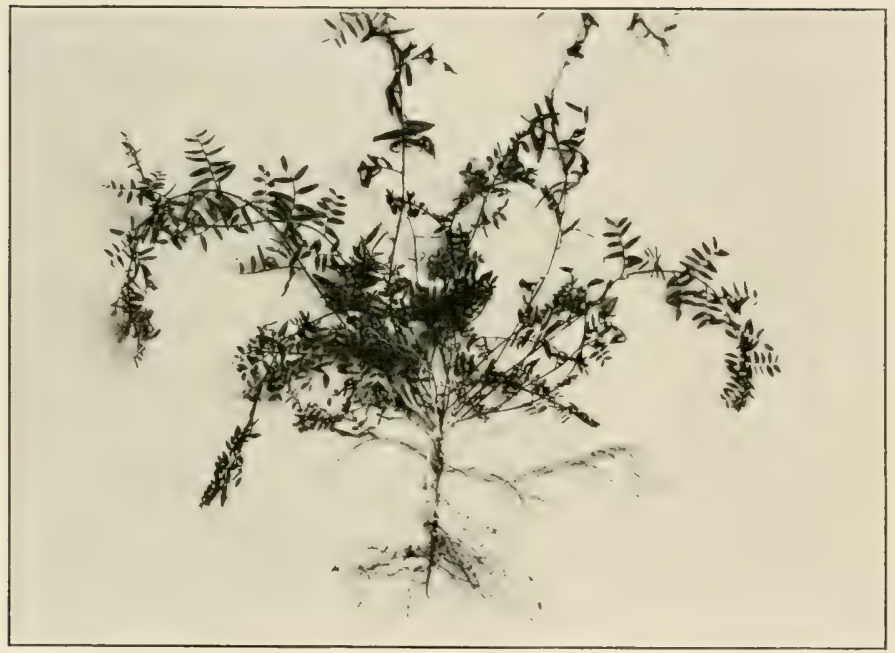

A Young Vetch Plant Showing Nitrogen Nodules on Its Roots.

Taken from the soil January 20, 1910. Note large number of branches shooting out from main root stem. The stems were more than a foot in length. 


\section{CHAPTER VII.}

\section{How to Get Organic Matter Into the Soil.}

Seeing the importance of drainage and soil rentilation, and that organic matter is an aid to both chainage and soil rentilation, then how can we get organic matter into the soil?

Plowing under corn stalks, weeds and stubble is one of the ways, and none of this precions material should ever be destroyed by the match.

Blue grass or clover sod is always rich in organic matter, but are not always available on the farm.

The best and quickest organic producers on the farm are rye, hungarian and retch. IVe will consider them in their order.

\section{Rye.}

Examine the rye plant and its roots in the early spring and you will find the soil completely corered with the foliage of the plant, and the soil for six or more inches in depth a perfect mass of roots. Plowing rye is like plowing grass sod.

The rye plant covering the soil during the winter season prevents the disastrous leaching that occurs on soils not covered. The foliage and roots give humus and ventilation to the soil.

It is said on the best authority that green rye is equal, ton for ton, to stable manure, with one small exception. 
Manure has half a pound of phosphoric acid per ton more than rye.

In a ton of green rye there are eleven pounds of nitrogen, four and one-half pounds of phosphoric acid and twelve and one-half pounds of potash.

A ton of green clover contains only twelve pounds of nitrogen.

Rye sown early in the fall will by May $\mathrm{I}$ produce five to fifteen tons of rye to the acre. This plowed under on that date would give you, compared to manure, a money value of $\$$ Io to $\$ 20$ per acre procured at an expense of less than $\$ 2$ per acre. In addition to its manuring value. it can be grown at the time of the year when much of your soil is not occupied with other crops.

It is a protection to fields liable to washing. It absorbs certain useful minerals and acids that otherwise would be lost to the soil.

One writer, speaking of rye, says: "The labor of applying erenly forty loads of manure per acre is considerable. All this is done more evenly by the green crop. Seed and labor together cost me but three dollars and a half per acre. I camnot say that it adds as much fertility to the soil as forty loads of manure, but I do say that in our droughty seasons it produces as great an increase of crop as do forty two-horse loads of good manure. It certainly pays to practice it, and to practice it largely, even on the land well supplied with stable manure."

In the fall of 1907 I planted rye in corn. The fall was the dryest we had had for years, but notwithstanding the extreme drowght the rye made a splendid srowth before winter and covered the ground. Some of the rye was plowed under quite early in the spring, and some on high rolling ground was not plowed moler until it was heading. The entire field was planted to sweet corn. In breaking the field the soil broke and turned over as a sod field would. The soil was loose and friable, and a splendid crop of sweet corn was grown. The corn grown on the 


\section{PRODUCING ORGANIC MATTER-RYE}

higher and rolling portion of the gromel and which was plowed when the rye was in hearl produced more per acre than the remainder of the field, and yet this portion of the field was the poorest.

I had another ten-acre field, which I also planted to rye in the fall of 1907 . This field was subject to much washing. but the rye covered the ground so completely before winter that no portion of the field was washed. In the spring I early plowed this field and sowed it in peas for a canning factory. The peas were harvested July 7,8 and 9. After the removal of the peas I disced the field and July is sowed to hungarian. September 6 I began cutting the hungarian for hay. It produced three and one-half tons of splendid hay per acre, ecpual in feeding value to any hay, except alfalfa, grown on the farm.

On the 2oth of September with a disc wheat drill I sowed the field to rye without any preparation of the soil. liy December I the field was a solid mass of green rye. This field I will break early in the spring and plant to field corn, and I know the field will be in splendicl tilth for same.

In growing rye for fertilizing purpeses most farmers make the mistake of pasturing it too close in both fall and sprning. In no case should it be pastured in the spring. Allow it to grow as long as you can. You camnot have too large a growth to plow under. Some may tell you that if you allow it to get too large and plow it under it will so dry out the soil as to injure the growing crop. But do not believe it. Ileary regetation plowed muler is a conservator of moisture.

Some will also tell you that it sours the soil. Your soil is sour only when it is cold, wet, non-ventilated and unproductive. Ditch and get the water out of it, plow into it large quantities of vegetable matter and thus start up the circulation of air into it, and it becomes warm and sweet. 
Soil is never soured by plowing under green crops if it is well drained.

Next to draining and ventilating, sont soil needs feeding organic matter. A fertile soil is never sour.

While rye is one of the most valuable of forage plants, yet it is equally as valuable for fertilizing purposes. If your soil needs cleaning, sow rye. It gathers food in the soil and makes fine growth on ponr soils. It is especially adapted to sandy lands and will grow well on stiff clay lands if they are well drained.

The author knows of a farm that has been restored and built wp with rye until it produces the best corn crops of any farm in the neighborhood. The owner always sows rye for plowing under for his corn crop.

His rye crops plowed under helped his land in holding moisture in dry seasons, which, as I stated, is contrary to general belief.

The farmers have a wonderful weapon in rye to aid in combating soil exhanstion, and it is so easily and cheaply. grown. From one to two bushels of seed at a cost of from 70 cents to \$i per bushel will seed an acre, and the labor of seeding in corn or after wheat is insignificant.

We who are sentimentally inclined delight in the melodies of the Scottish love lyric, "Comin' Thro' the Rye," humming its words:

"If a body meet a body, comin' thro' the rye, If a body kiss a body, need a body cry?"

We wonder whether the Scottish bard was singing of the rye plant or of the River Rye and its stepping-stones o'er which the Scottish maidens were wont to pass, for if he was singing of the rye plant we can picture in our imagination the lovely scene of a field, rich in the beatitiful growth of the majestic, blooming rye plant, whose foliage hid the blushes of the Scottish maiden when met by her stalwart lover, "Comin' Thro' the Rye," who claimed the coveted kiss. 


\section{PRODUCING ORGANIC MATTER-RYE}

But we who have no sentiment in our hearts and look only to the material worth of things. can find in the rye plant those elements of plant food that quickly and cheaply build up our soils to the highest and best fertility.

We so little appreciate the good things that fod has provided for our welfare, and rye is one of the least appreciated crops on the farm. Aside from its great feeding value, it is one of the best soil builders, and is always so available and so willing to respond and give its best service to us under the varied conditions of soil, weather and seasons. 



\section{CHAPTER VIII.}

\section{Hungarian.}

Hungarian is another one of the most valuable and less appreciated crops of the farm. Fin feeding purposes, for both cattle and horses, I rank it above clover or timothy hay. It is said to injure horses. A greater fallacy never existed. Cut just when the seed has formed, no injury results from feeding in any quantity. I have fed it for years to the best of horses, and they relished it and thrived upon it. It is the quickest and cheapest hay crop grown. It can be sown in July after a wheat, oats or pea crop has been removed, and in eight weeks or less a crop of hay can be gathered making from two to four tons to the acre, and after the removal of a crop of hungarian the land can be seeded to rye or wheat.

I have heard it said that it is a soil robber. I have not found it so.

A ton of hungarian extracts from the soil but eight pound of nitrogen and eight pounds of potash more than a ton of green clover extracts from the soil.

For loosening up the soil nothing equals it.

Last season I had a field in corn, one-half of which the previous season had been in hungarian for hay, and there was no difference in the yield of the corn, but that part of the field previously in hungarian was more easily cultivated.

Farmers will condemn hungarian without foundation. and say that it is a robber of the soil, and yet raise year 
after year timothy, which I say and can prove is the meanest soil robber on the American farm. Mean, because I know of no more certain way to hasten the total exhaustion of the soil than to grow timothy year after year. On my farm I shun it as I would a rattlesnake. It takes six years of the best of treatment to rebuild soil upon which timothy has been grown for three or four years.

I know of fields, once rich, almost utterly made unfit for the growing of crops by the growing of timothy on them for a great number of years.

If I was forced to buy hay, I would rather pay $\$ 20$ per ton for timothy hay than grow it on my farm. But I have digressed. I was to say something of the value of hungarian as a producer of organic matter.

It is said that a ton of hungarian in 1)lossom contains twenty pounds of nitrogen, five and one-half pounds of phosphoric acid and seventeen pounds of potash.

It takes from one to one and one-half bushels of seed to sow an acre, worth generally from \$i.50 per bushel, or $\$ I .50$ to $\$ 2.25$ per acre. If but three tons of lungarian to the acre is grown and same is plowed under, you get 60 pounds of nitrogen to the acre. It will take six tons of harnyard manure to produce 60 pounds of nitrogen. and six tons of manure is worth not less than si.5o per ton, or $\$ 9$.

In addition to the large amount of nitrogen and potash in a ton of hungarian, think of the vast quantities of organic matter to plow under and available as humus, and for loosening up the soil and for soil ventilation.

If hungarian is used as a plowing under crop, I would adrise sowing it after the wheat or oats crop is gathered. discing or plowing the ground deep, then when hunsarian is in blossom and before the seed has matured, plow under five or six inches deep and sow to rye. You then have the advantage of from two or three plowings of the soil during a season, which I have shown to be a 


\section{HUNGARIAN}

manuring in itself, as "tillage is a manure." Your soil is also covered during the leaching season, and has in the spring another valuable soiling crop for plowing under

By a little hustling a crop of hungarian could be sown after wheat, plowed under in time to sow wheat in the fall and which wotnld be of immense value to the wheat crop. 


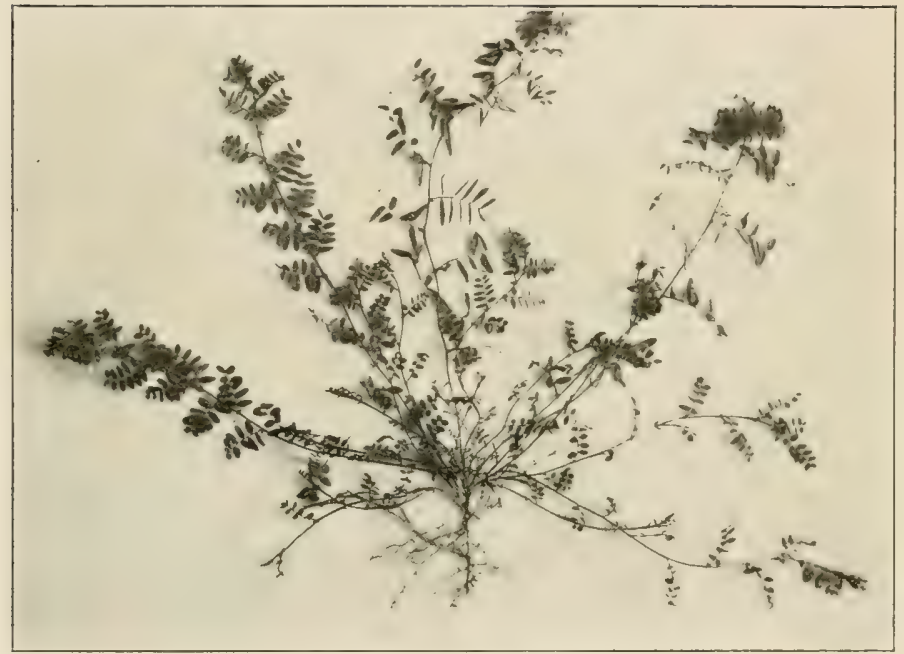

Vetch Plant, grown from seed planted August, 1909; taken January 20, 1910, from hard frozen soil, which had been subjected to a temperature of 17 degrees below zero. The plant was fresh and green, showing no effects of the severe freezing.

Note the large four-pronged nodule on end of main root stem. On account of hard, frozen ground, most of the roots of the plant were broken off in getting it from the frozen soil. 


\section{CHAPTER IX.}

\section{Sand, Winter or Hairy Vetch.}

Four years ago the author purchased a farm that hact the reputation of being one of the pourest in the conntry. It had been kicked and buffeter about as trading stock. Each owner no sooner got into possession of it when he found he had purchased a "gold brick," and never rested until he suceceded in mulualing it $11 p$ on some other victim. It never seemed to occur to any of its owners that the farm had simply been handled by soil robbers and was paying the penalty by withdrawing its bounty.

The anthor purchased this farm because of its cheapness. location and possibilities, and was given the langh for so doing.

The character of the soil and lay of the land is peculiar. ( )ne-third consists of deep) yellow sand, placed in ridges, no portion of any extent being level. One-third is level, sandy loam and the other third black II abash bottom land.

The entire farm in its early history was covered with large walnut, poplar, oak and other timber, the timber on the sandy land having been as heavy as on the other portion of the farm. The land was a portion of an Indian reserve, set apart by the government to the Indians in I 818 and by the Indians sold in 1833 , and was cleared more than sixty years ago, and for many years produced large crops. It had always been farmed upon the principle of getting out of it all you can each year and put- 
ung nothing back into the soil. Lnder this system of farming the sandy or two-thirds portion of the farm had become so poor that in the best season it produced but 15 to 20 bushels of corn, 5 to Io bushels of oats and Io Dushels of wheat to the acre. Some seasons corn, oats and wheat were an entire failure. Even the black bottom portion was farmed in corn year after year until the yield fell to less than fo bushels to the acre. In finc, the farm was just on the borderland of the abandoned farm.

As the author has been up against many of the hard propositions of life, it did not take him long to learn that in acquiring this farm he had tackled more than he had anticipated. He was like the Indian who was being worsted in a hand-to-hand conflict and who exclaimed, "Me in a heap big fight."

To reclaim this land, the author soon realized, would require some work and study.

The first season he planted the sandy portion to early peas for camming purposes. Seven weeks of dry weather reduced the crop to a money value of \$io per acre. L ${ }^{\top}$ pon the removal of the peas the land was disced and planted in sweet corn before Jume 25. The sweet corn brought a money value of $\$$ I 5 per acre.

Various crops were grown on the farm the first season, to-wit: Peas, sugar corn, canning beets, field corn, tomatoes and potatoes. Some commercial fertilizer and manure was used; the commercial fertilizer with little or no success.

Had it not been for twenty acres of late peas sown on the bottom lands that brought a money value of $\$ 75$ per acre, the farm the first year would not have paid expenses.

But the author was not discouraged. He was constantly studying conditions and looking about for something and some method by which the soil of his farm could be rebuilt.

One day during the first summer he received through the mail a catalogue of a seed house, and in turning its 
pages his eyes caught the words "Sandy Vetch." The fact that he owned some sand that was then the uppermost subject in his mind no doubt had something to do with arresting his eyes upon the words.

Reading the description in the catalogue of this plant, which said that "Sand Vetch was becoming more pop" nlar with the farmers of the country as they learned more of its value; that it was noted for its extreme hardiness. its value as a cover crop and for forage and fertilizing purposes; that it was especially recommended for poor soils where it thrives wonderfully and improves the soil. being rich in nitrogen," the author began to "sit up and take notice."

It did not take him long to learn that he was interested and intensely interested. liut when he real further that "the IVashington Department of Agriculture estimated the value of an acre of retch plowed under as equivalent to putting into the wround twenty or forty dollars worth of commercial fertilizer," he became enthusiastic. Ile was ready to shout at the top of his roice "Eureka!" liut he read on until he came to where the description said: "It is suited to any soil, and is valuable in this respect, as it produces good crops on poor sandy soils, while on good land it grows to a height of four or five feet and produces enormous crops."

This was enough. He was convinced that he had been rewarded in his search, and had indeed found the precions alchemic soil-enriching art for which he had been searching, and immediately sat down with "pen in hand" and ordered seed enough to sow two acres. Yes, two whole acres!

And now, in the light of four years' experience with this valuable plant, the author smiles when he thinks that, being up against one of the hardest propositions of lis life, and having placed in his hands the rery thing that would overcome it, he only had nerve enough to order enough retch seed to plant two acres, for had he 


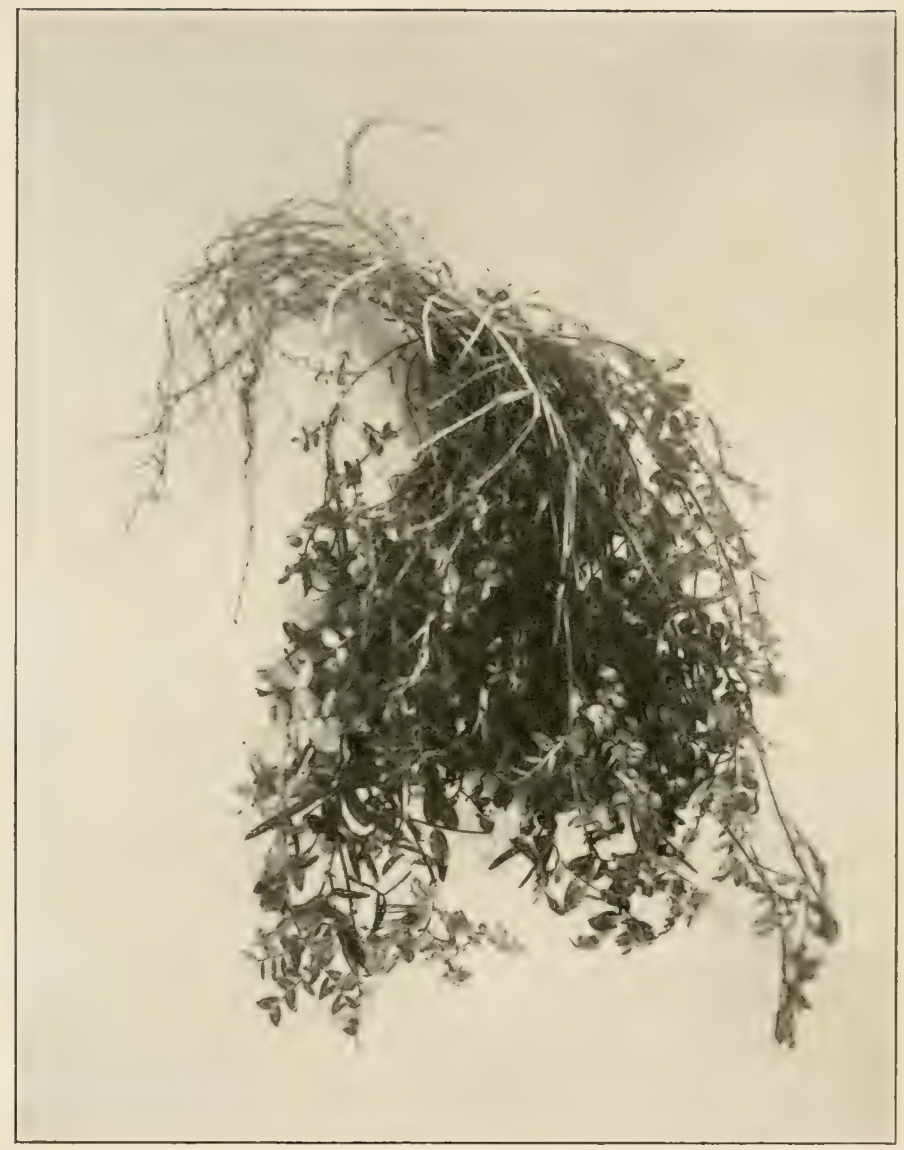

A bunch of Vetch taken from under ice and water, which had been standing on same for three weeks, in January, 1910. The plants were bright and green and showed no injury. 
possessed the nerve to, have ordered enough to plant his entire farm, and then the following spring planted the same in field corn, as subsequent experience demonstrated, he would have received from the corn crop the purcliase price of the farm.

In due time the seed was received, and in August it was planted upon the poorest and most rolling two acres of sand land on the farm. It grew rapidly, and by winter the ground was so completely covered with its foliage that washing of the land was entirely prevented. An examination of the roots showed them set thick with nitrogen nodules. Early in the spring. before any other kinds of grass or vegetation began to grow, the vetch plants were pushing out their summer foliage, and by May I they were four feet in length. About the first of June the two acres were cut for hay.

The author saw clearly that he had found a valuable plant for the farm, yet exemplifient nsual caution by planting only 25 acres of vetcli in August of I907, the sowing being on the poorest and sandiest land of the farm, 2I acres in one field and four in another. It was decided to seed the 2I acres to field corn and leave the other for pasture. Both grew luxuriantly.

The spring of 1908 was very wet, and it was May I before the ground was in condition to break for corn. Delays were such that the 2 I-acre field was not entirely broken until May 25. The retch had grown to a height of five feet, and the mass of regetation was so heavy that it was almost impossible to turn it under. A half dozen makes of plows were tried with complete failure, when finally suceess was obtained with a double disc plow, and the field was finished. The prospect did not look inviting. for bunches of retch showed here and there sticking ont of the ground. The field was worked down to fairly good condition for planting by dragsing and rolling. and on June 3 and 4 was planted to yellow corn.

Dire were the predictions made as to the outcome. 
Nany contended that the heary mass of regetation would absorb all the moisture from the ground and the corn would perish. And it cannot be said that the author was fairly hopeful. But he gritted his teeth, held his commel and awaited results. The corn came up a splendid stand. Dry weather set in, which adderl no little discomfort to the situation. The corn grew slowly, and as soon as it was sufficiently large the cultivators were set to work, and were worked with a little difficulty on account of bunches of the vetch insufficiently plowed under catching on the cultivator points.

It was amusing to hear the side remarks of the men working the cultivators, which would indirectly come to the anthor's ears.

One day, when the corn was receiring its first plowing. two hardware men from the city came out to set up and start working a new two-row cultivator. When they were taken to this field disgust was plainly shown upon their comntenances. One of them, after the corn grown in this field had been harvested, told the author that when he first looked upon the field he said to himself that in all his forty years experience as a farmer and seller of agricultural tools he had never seen so unpromising a prospect for corn as this field presented.

As stated, the weather was dry, and the corn grew five or six inches high, and made no further growth for more than a week, when it seemed to take on new life, and then how it did grow! My, the pride the author did take in that field of growing corn! How it sparkled his eyes and swelled his pride to look upon it! He felt the glory of having done something worth while. The neighbors and travelers along the highway began to take notice as the corn grew and grew like Jack's famous bean stalk.

The corn, notwithstanding the rolling and hilly character of the field, was of the same height, every hill alike. and of the dark green color indicating the healthy growth of corn. 
When the corn reached waist height the prophets who had predicted its nntimely demise on accomnt of the great mass of retch turned under said: "Nait until it begins to ear, and then you will see it fire and wither up."

But the corn grew up and up until it reached the height of eight to ten feet, silked, tasseled, and bore its ears of golden corn.

It was subject to six weeks of dry weather after it had silked, and yet it had not fired and every hill was bright and green. The neighbor's corn opposite and across the public hishway fired clear above the ears of corn, and rid not make 20 bushels to the acre.

Residents of the county not acquainted with what had been done to the field. who had been passing this field for twenty years or more, attracted by the remarkable growth and condition of the corn, would stop, get ont of their velicles and go over into the field to examine it, and then stop) at the house and inguire what had been done to the soil to cause such a growth of corn, saying that "they had never known this field to have upon it a crop of corn of any value; that corn on this field was almost invariably a failure."

The corn finally reached its harvesting stage, sound and solid. It was gathered, hanled to market, and made by weight 72 bushels to the acre, and brought a money value of $\$ 35$ per acre.

The planter used to plant the corn was set to drop three grains to the hill, and never missed putting three grains in the hill, but too often dropped four grains, which made the corn too thick, and this condition fully reduced the vield ten or more bushels to the acre. But think of 72 bushels of corn being grown on land that had not for twenty or more years produced more than 20 bushels to the acre, and this feat accomplished in so short a time and with so little expense, as the cost of the seed was but $\$ 3.50$ per acre. 


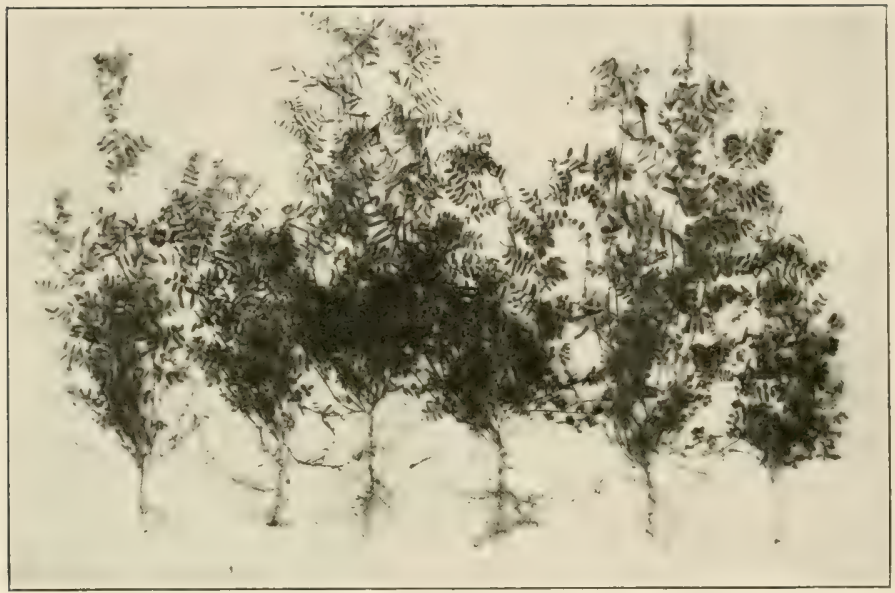

Vetch plants, taken January 20, 1910, from top of high sand ridge, exposed to winter winds, which kejt the ridge bare of snow. These plants had been subjected to a temperature of 17 degrees below zero, without any snow covering, and showed no effects of the weather they endured. 
This experiment with retch made the author a retch enthusiast.

In August of the year inos he planted thirty acres. and notwithstanding the extrene dry fall, there having heer: no rain for eight weeks after it was sown, it grew nicely.

In the spring ten acres of it was plowed for field corn, seren or eight acres for potatoes, and the balance for sweet cor11.

The illustration in the front of this book shows a view of the pourest part of the fielel of corn taken September I909.

Lpon this particular spot of ground shown in the picture corn had never grown to exceed a height of four or five feet, with a correspondingly poor yield. Here the vetch was the heaviest, being four or five feet in height when plowed under in the middle of May. The soil on this particular spot is a sandy clay, the remainder of the field is a black wambu soil : the whole having been farmed for a half century with a rotation of corn, oats and wheat, a greater majority of the years in corn, and every year the corn stalks were burned. In recent years the yield of corn had been from almost a failure to 40 bushels to the acre. The yield after the vetch was nearly 90 bushels to the acre of large, splendid white corn-an increase over former years of over roo per cent. The cost of retch seed for this field was $\$ 3$ per acre.

The author's brother is the owner of a farm the soil of which is clay underlaid with a gravelly sub-soil. When first cleared, more than sixty years ago, it was rich and produced enormous crops. Fifty years in the hands of tenants, with an insufficient soil-building material adderl to it, reduced the yield of corn to less than 30 bushels to the acre. In the fall of Igo8 fifty acres of this land was planted to vetch. The extreme dry fall made the seed come up slow and nneven, and only a fair growth was obtained before winter. At plowing time the following spring a fair crop of vetch was plowed under and forty 
acres planted to field corn. The crop gathered from the field corn produced over zo bushels of corn to the acrean increase of over Ioo per cent.

Ten acres were plowed under and the ground cultivated until June, when it was planted to alfalfa, about which we will speak later. Another vetch enthusiast was added to the list.

Both author and brother have at this writing (December 20 , Igog) vetch growing on their farms, sowed in the open and in corn, that covers the ground like a thick velvet carpet.

The author's experience with vetch for potatoes and sweet corn has been as successful as it has been with field corn. Sweet corn has been grown after vetch on poor soil that produced from $4^{\mathrm{I} / 2}$ to 5 tons to the acrea money value of $\$ 36$ to $\$ 40$ per acre. In rgog one and two-fifths acres of potatoes planted after vetch on soil deficient in fertility produced nearly +50 bushels, and potatoes planted after vetch on some of the sandiest land on his farm produced at the rate of $\mathrm{I} 5 \mathrm{O}$ bushels to the acre, and double the amount of potatoes grown side by side on the same soil after crimson clover plowed under.

No Anubt the question suggested to the reader's mind is, Why is vetch of so much value as a soil or fertilizer crop? The question may be answered with a few words. It is the greatest nitrogen-gathering and humus-producing plant found in nature's garden.

We believe it to be true as holy writ that for every disease of the human body nature has a remedy if man can only find it, and that for every disease of the soil there is a remedy to be found in the plant, mineral or animal kingdom, and it is up to man to find and apply it.

If soil was originally built up by mixing vegetable matter with disintegrated minerals and stones, then why can it not be kept built up by the same process?

Lnder Southern European skies retch is supposed to have had its birth. In all Europe it is cultivated for 
forage purposes, it being regarded as erpul to clover in nutritive qualities. Sown in late summer or early autumn, it is harvested the next year. If in the spring, it is cut the same year.

The American farmer, slow or overly cautious in trying the unknown, has rarely cultivated it. Is stated, it is an annual plant, and must be seeded each year, although it readily reseeds itself, as I have pastured it with cattle, taking the cattle from it as it began to seed, and then allowed the seed to ripen and fall upon the ground, discing the field thoromghly, and the seed came up), giving me a fine stand.

Tetch being rarely cultivated in America, the supply of seed is, as a consequence, procured in Europe and imported to this country at a cost to the farmer of $6 y_{2}^{2}$ to Io cents per pound f. o. b. shipping station.

Fifty pounds of seed to the acre is the right quantity to plant.

In corn I sow the seed with a one-horse hoe or disc wheat drill. In the open I sow with a two-horse drill. The feed gange of the arerage one or two-horse drill entirely shut off sows just 50 pounds to the acre.

If vetch is sown for seed, there must be sowed with it about one peck of rye to the acre. The rye holds up the vetch so it can be easily harvested. The plant is a trailing one, and hence is hard to harvest muless it has a plant sown with it to support it.

When seed is ripe, cut and thresh with ordinary threshing machine and separate seed with fanning mill.

seed for planting can be procured from most any seed house.

The reader must bear in mind that the author is writing about Sand, Winter or Hairy Vetch. He knows nothing about other varieties, which no doubt are valuable, but the author has not tried them.

The retch plant has a mass of roots penetrating the soil to a considerable depth. The roots are always full 
of nodules, the homes of the bacteria that obtain their food from the nitrogen of the air, and which it is claimed collect more nitrogen than they need. which surplus is stored into the soil.

The clover, alfalfa and pea plants and other plants of the legume family are comsidered valuable to the soil becanse of their nitrogen-gathering powers, they having these nodules on their roots; but a retch plant will have ten nodules on its roots where these other plants have one.

The vetch roots are so $11 m$ merous in the soil that it will plow up like a heavy sod. The foliage of the plant is so massive that it produces from twelve to twenty tons to the acre. There is no plant of the nitrogen-gathering species that produces such a quantity of organic matter for plowing under as is furnished by the vetch plant.

When plowing up the 2 I-acre field mentioned in the beginning of this chapter the next spring after the large corn crop had been grown, the anthor observed that the corn roots had pushed their way down into the mass of vetch plowed under, and had interlaced themselves around the vetch stems until the whole mass had been knitted together, and, the plow turning it on top of the furrow, it looked like sheep skins spread out on the ground. On exposure to the air the mass fell into small pieces.

This observation proved to the author that the corn roots had found in this mass of vegetable matter a great feeding ground, where both feed and mosture was found in abundance for the feeding of the corn plants.

After four years' experience with it I am convinced that the claim of the Agricultural Department that an acre of it plowed under is equivalent in value to twenty to forty dollars is not extravagant.

It is the greatest soil builder ever discovered, alfalfa not excepted. With it and fitching I can reclaim any poor or worn-ont soil. With it the American farmer can 
make his soil produce as it has never produced since it was rescued from the wilderness.

Vetch is the remedy for clover-sick soil. If alfalfa is the most valuable forage plant ever discovered, vetch is the most valuable fertilizing plant ever discorered.

Vetch builds on its roots so many pretty little homes for the busy nitrogen-gatherers, who so mysteriously draw from the great storehouse of nitrogen situated in the air above the soil great quantities of the precions. most valuable acquisition to the soil, nitrogen.

Vetch is no respecter of soils. It settles down and makes its home with the rich or pour clay as well as the rich or poor sand, and commences its business of soil restoration at once. It has no terrors of frost or drought. Winter will grasp it with its hand and hold it in its icy grasp for months and months, and when the warm smshine of spring releases it. it smiles with its freshness of green and continues doing business at the old stand. The drought of fall, spring or summer will blow its oven breath upon it, but it heeds it not, and continues its business of storing fertility in the soil as though it was being constantly caressed with refreshing showers.

It finds the soil sick, impoverished and dying. It touches it with its restoring power, and under its stimulating tonch the soil awakens with new and renewed life. pouring out its wealth of plant srowth that ripens into food for beast and man.

It will get enter npon the abandoned farm, banish the desolation of the fields, fill the monocupied farm lonse and barns with the songs of happy, prosperous parents. the langhter of children and the riches of fertile fields.

All hail King Vetch, Nature's greatest soil restorer! 


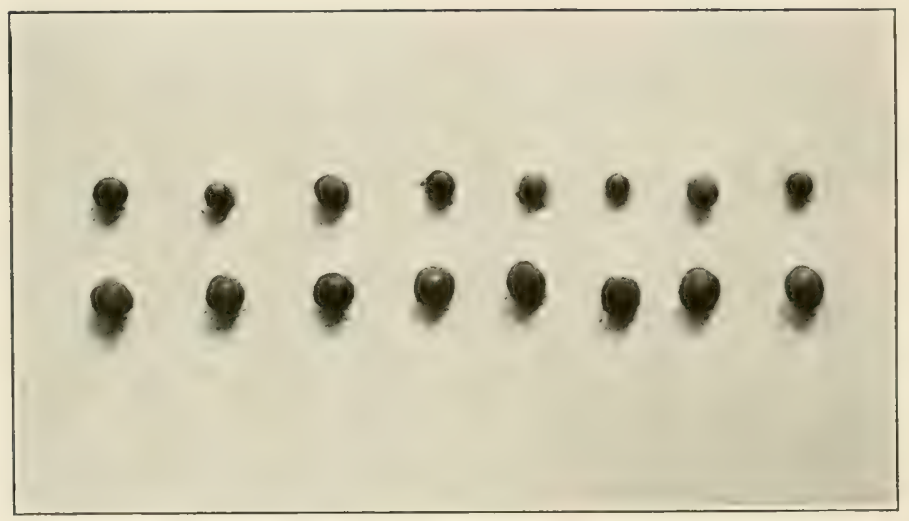

Vetch Seed Actual Size.

Top row, Sand, Winter or Hairy Vetch.

Bottom row, Spring Vetch.

The Sand, or Winter Vetch seeds are round, hard and of a bluish black color and size of No. 2 and No. 3 shot.

The Spring Vetch seeds are a third larger than the Winter Vetch; in color are gray mottled, and are not round but somewhat flattened. 


\section{CHAPTER X.}

\section{Vetch and Alfalfa.}

The value of alfalfa on the farm cannot be estimated. No plant has so many uses. If the corn plant should become extinct, allalfa could take its place, fill every want that corn supplies, and yet its storehouse of utility would still be overstocked.

The usefulness of the alfalfa plant has been so beautifully and eloutently pictured by the great alfalfa apostles and experts, (olburn. Clothier and IVing, that we feel that were we to enter the field of alfalfa picture-painting our efforts would be in vain.

IBut, considering the great usefulness of this plant, it is astonishing that the American farmer grows so little of it. It cannot be on account of ignorance, for the American farmer is surely enlightened upon the subject of alfalfa growing. It must be the habit of farming "just as father did," or the slowness of taking on the new or unused thing, that keeps the farmer from planting alfalfa on his farm.

However, I find on inquiry some farmers say that the reason they do not grow it is becanse it is hard to get it started; that it requires so much labor and patience to get the proper stand and start. Whether there is any truth in this I am not prepared to say, but I do say that with vetch I can start alfalfa on almost any soil that is properly drained.

Authorities on alfalfa will tell you that the alfalfa plant 
when first started must get its nitrogen, which is necessary to its life, from the soil; that after the plant is well established it draws its supply of nitrogen from the air. That for this reason you must have your soil innoculated with nitrogen-gathering bacteria, and have plenty of nitrogen in the soil, or you cannot get the alfalfa plant to establish itself. Then, this being true, some method must be used to secure the supply of nitrogen and nitrogengathering bacteria in the soil intended for the alfalfa field. Tarions methods of doing this are given by alfalfa experts, such as soil innoculation by taking soil from alfalfa fields and spreading upon the field before sowing the alfalfa seed, heary manuring, sowing alfalfa meal with the seed, and feeding alfalfa hay to stock a year before alfalfa is planted and using the mantre on the field.

My experience with vetch has demonstrated that for starting alfalia. vetch, on account of its nitrogen-gathering qualities, has all other methods of soil innoculation beaten to a finish.

I spoke of ten acres of alfalfa planted in June, I9o9, by my brother un clay land. This field has been cleared for more than sixty years and farmed almost to its death. As stated, it was planted to retch in August of Igos, and plowed under in May, I909, before it had ripened its seed. The weeds were kept down by frequent cultivation wntil the middle of Jume. when alfalfa seed was sown at the rate of twenty pounds to the acre. In four weeks the alfalfa was six or eight inches in height, and was clipped with the mower, clippings left lying on the ground. In five weeks it was clipped the second time. On December 3 I examined this field, and it was green and a splendid stand, and promised to be a fine alfalfa field.

August 16, I909, I planted fourteen acres of alfalfa on the sandiest portion of my farm that had formerly been in vetch, and in five weeks it was six inches high and a 
splendid stand. The field was clipped, and it has gone into winter in splendid shape.

From all this I conclude that retch is indeed a valuable plant for preparing the way for alfalfa. . 


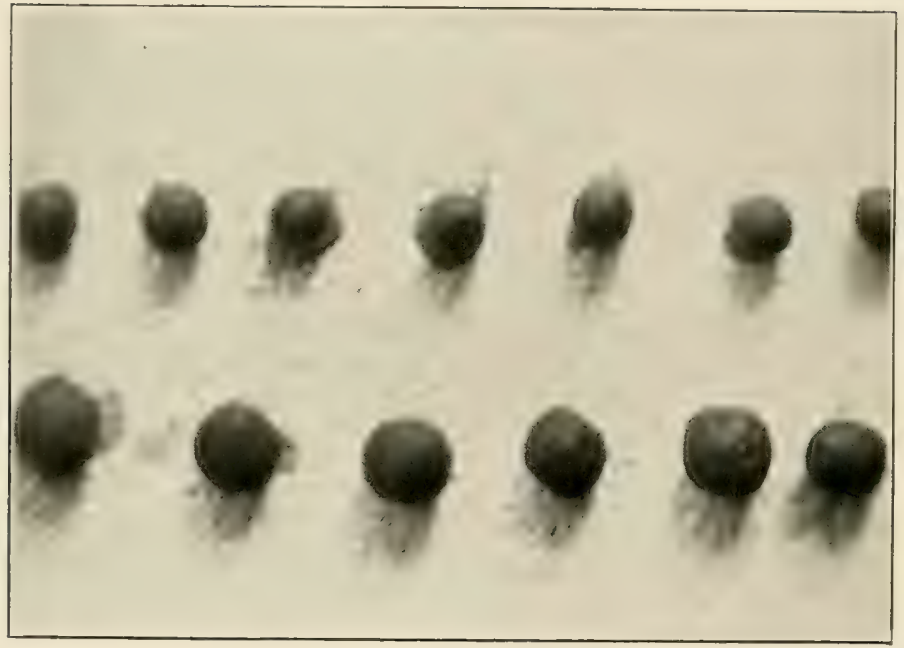

Winter and Spring Vetch Seed Magnified Several Times.

Top row, Winter Vetch. Bottom row, Spring Vetch. 


\section{CHAPTER XI.}

\section{My Method of Restoring Worn and Worn-Out Soils.}

If I had placed in my possession worn or worn-out soils at the beginning of the present year of 1910 . I would proceed to restore them in the following manner:

If I lived in the vicinity of a canning factory that canned peats and sugar corn. I would first see that the soil was thoroughly ditched; then I would plow it as early in the spring as possible and plant to early peas. The crop ought to be ready to remove by June I5. I have removed them June Io.

Immediately after the peas were harvested, I would have the ground thoroughly disced and planted to stugar corn. This crop should be well cultivated and kept clear of weeds.

If the soil was much worn it is probable you would only receive from the crop of peas and sugar corn enough money to pay expenses, but you would be well started on the road of soil restoration, and that start must be made.

Early in August I would plant in the sugar corn either vetch or rye. My preference would be vetch always.

Under no circumstances would I pasture the stalles of sweet corn, althoigh they are of great value for this purpose. but you must remember that you are engaged in the business of snil-building, so do not let greed get the upper hand. Leave the stalks alone for plowing under with the vetch.

In the spring of next season, about the Ist of May, I 


\section{RESTORING WORN AND WORN-OUT SOILS}

would plow under the retch and stalks, and about the Ioth of May plant to field corn, giving same thorough cultivation, and when same was plowed the last time. would sow to rye or vetch. In this case I would as soon sow rye as vetch.

I would not allow the corn or rye to be pastured, and the following spring would plow the whole under and plant again to field corn. Both these crops of field corn I know would produce to your surprise and the surprise of your neighbors, and you would be well along on the highway of building up your soil.

After the second crop of field corn the soil could be planted to wheat, followed with clover.

If you do not live in the vicinity of a canning factory, then your first planting could be either cow peas or hungarian, but these crops should be turned under before the ripening of their seed, and the soil sown to rye or vetch; my preference would be vetch.

The following spring plow up and plant to field corn. the same at laying-by time to be planted either to retch or rye, and the next season to be plowed up and put in corn, to be followed with wheat and clover.

I know that this method of soil-building will work grandly, for I have tried it.

With this method I can in two seasons grow from 50 to Ioo bushels of corn to the acre on most any worn-out soils.

On fairly good soils results will astonish you.

If you wish to start alfalfa on a piece of worn soil, and live near a canning factory, sow to peas as directed and follow with sweet corn and vetch; keep off stock and plow under vetch before ripening of the seeil, and keep cultivating your ground until middle of July or first of August and sow to alfalfa. Clip the alfalfa when five or six inches high, learing clippings on the ground, and clip again before winter if growth should be considerable.

If you do not live near a canning factory, sow hun- 


\section{RESTORING WORN AND WORN-OUT SOILS}

garian, and if ground is much worn, plow under before seed ripens and sow to vetch. But if soil is fairly rich, cut the hungarian for hay just as seed has formed, and then disc thoroughly and sow to vetch.

The following spring, in either of the above cases, plow mnder the vetch before it ripens its seed. Keep the ground cultivated until you are ready to sow the alfalfa seed, which may be any time from the midcle of July to the first of August, the earlier the better. If you use care in selecting and sowing your alfalfa seed, you will obtain a splendid stand and crop of alfalfa.

In case you plow under your hungarian you lose a year's crop, but suppose you do; you gain more than you lose in the fertility you gain and the condition in which you get your soil.

If your soil is not poor and you cut your hungarian, you will get a vast guantity of fine hay. which. as stated, we regard as the best hay that can be grown on the farm, alfalfa alone excepted.

Peas, hungarian and vetch planted in the manner we have stated blaze the way through the perplexities of compact, nom-innoculated soils to successful alfalfa growing. There is no doubt about it; try it and see.

I have elsewhere stated that it is a great mistake to allow soils to be idle. There is only one exception, and that is when you are starting a blue grass pasture.

The soil should ever be occupied in growing a crop intended either for grain, feeding or plowing under.

Field corn, after it is laid by, onght always to be sown with vetch, rye or clover, even if same field is to be put in corn the next season.

If wheat ground is to be followed with corn, the same should be disced or broken immediately after wheat is removed and sown to retch or rye, the same to be plowed under in the spring.

By following this plan you gain the advantage of tillage, soil covering, and getting organic matter in the soil. 


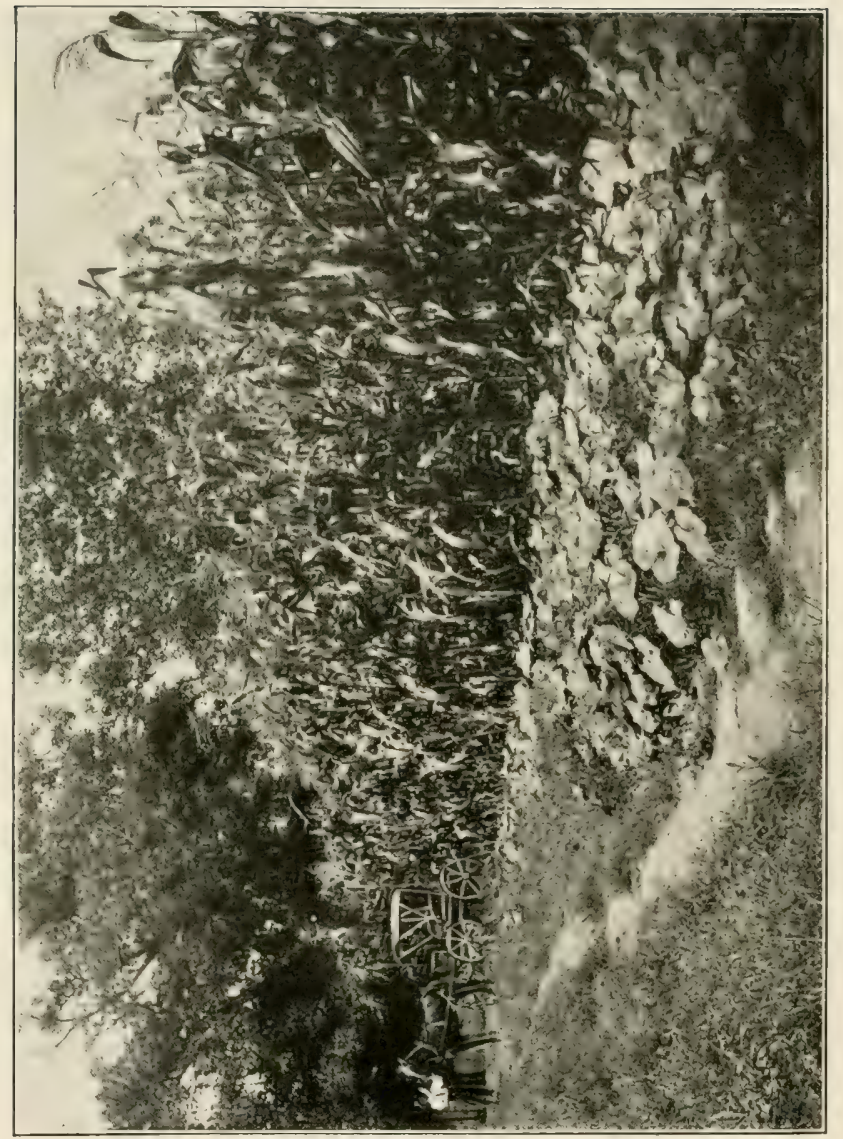

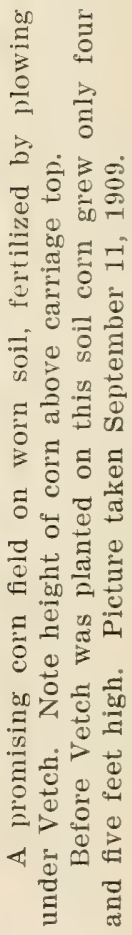




\section{CHAPTER XII.}

\section{King Corn.}

Corn has been proclaimed the King of all cereals, and who can dispute his title?

While corn is of one species, its varieties are numerous. It is one of the most beautiful and useful plants that grows. Owing to its being so common, we lose sight of its beauty, yet in parts of the world it is cultivated as an ornamental plant.

More people eat corn than any other grain except rice.

Corn is the farmer's best crop, because it not only furnishes food for himself and beasts, but returns the most money for the least labor and expense of any crop on the farm.

Corn is not adapted to all climates. But while it is affected by climate and soil, yet by continuous cultivation from the same seed, year after year, it can be made to establish itself in most any locality.

Corn, being distinctly an American plant, is produced chiefly on American soil. [int not all our soils will produce corn. The "corn bett" is limited, embracing chiefly the great States of Ohio, Indiana, Illinois, Iowa, Nebraska, Kansas and Missouri. Other States grow it, but not to the extent of the States mentioned.

There was produced in the corn belt in the year 1909 $2.772,367,000$ bushels of corn, and yet the price of corn is high, showing that the uses of corn are large.

The consumption capacity of the world for corn is so great that there does not seem to be any danger of an over-production. In fact, the demand for corn is greater 
than the supply, or the price would not be so high as it is now.

On account of our soils losing in fertility, the average bushels per acre is not increasing as it should.

If corn is the easiest, cheapest and best money-making crop grown on the farm, then farmers should become enthusiastic over any method that will bring about a greater yield per acre.

In the preceding chapters I have shown the original process of soil building and the hest methods of soil restoration.

The methods of soil building I have detailed are not chimerical, but are real, practical, cheap and at the command of every American farmer. They will put your soil in the right condition to grow Ioo bushels of corn per acre.

While good soil well prepared as a seed bed is the very foundation of a good corn crop, it is not the only thing needed to produce a large crop. You must have good seed. Seed selection is important in any crop. The loss occasioned by poor seed is enormous, and it can all be avoided with a little care.

Too many of us depend on our seedsmen, and as they assume no liability on account of poor seed, we are helpless if our seeds prove to be bad.

The author purchases every year for his own growing seeds amounting to thousands of dollars, and his long experience in the purchase and growing of seeds has persuaded him that there onght to be a drastic law regulating the selling of seeds. There are so many dishonest persons dealing with dishonest seeds that the honest dealer is uften imposed upon, but under present metlods the grower suffers the entire loss of poor, unreliable seeds.

Wherever it is possible to do so, the farmer should grow his own seed crop. When it is necessary to purchase, deal only with reliable persons and houses. 
Seed corn is so easily grown and cared for. It is said that the best time to begin selecting seed corn is while you are cultivating the corn, by noticing the most promising stalks and ears, but as we are usually too busy at this time to do this, the practical time to select is at husking time.

In selecting seed corn, the stalks and husks should be first noticed. The ear should be on the stalk at a medium height from the ground, and the ear should bend downward.

The husks should cover the ear entirely. The following rules for selecting good seed corn are as good as any that can be given:

"The ear shonld be full and strong in midclle portion. The circumference in the middle should be about threefourths of the length of the ear.

"The rows of kernels should be straight, and not less than 16 nor more than 22 in number.

"The length of ear should be not less than $8 / 2$ inches.

"White cob in yellow corn or red cob in white corn disqualifies.

"Twelve or more foreign kernels disqualifies.

"The kernel shomld be twice as lone as it is broad and of medium size. The edges should be nearly straight, so as to leave only a slight crease between rows on outside of ear.

"There should be no space between the tips of the kernels, either on sides or edges.

"Kermel indentation should be regular and fairly deep, but not pinched, which would make crown chaffy. The kernels slould be uniform in shape and size.

"The ear should be firm and sound. The germ should be well developed, indicating strong vitality."

Seed corn should never be exposed to freezing weather unless it he thoroughly dry, and should be put in a dry place, where ventilation is perfect.

The time and method of gathering seed corn, as given 


\section{KING CORN}

by the Agricultural Experiment Station of Purdue Lniversity, is so practical and good that we quote them in full:

"To get the best seed corn it should be selected in the field after it has matured and while the characters of the parent stalk can be observed. This can be done to the best advantage by going through the field aiter the corn is mature and before the general harvest begins and picking ears of good size and quality from the stalks that are strong and vigorous looking, but not coarse. There should be a large leaf development. The leaf is the laboratory of the plant where the food it gathers is mam1factured. The stalk should be of medimm size, strong at the base and tapering gradually to the tassel. It should stand up) well and bear its ears at a convenient height for husking. The shank should be of medium length and strength. A short shank holds the ear too erect, while a long shank allows it to hang over too far. Ears on long shanks or high up on the stalk are more likely to pull down the stalk during a wind storm, besides being inconvenient to husk. The ears selected shonld be strons and well developed, with straight rows of regular sized kernels. The kernels should be rather deeply dented. The smoother kernels are generally shallow and will not produce so well. The seed ears should always be a little rougher than the average of the crop, otherwise the variety will become smonther each year and the kernels shallower. The dent, however, should run squarely across the kernel, and there should be no sharp or pointed margins.

". Seed corn should never be picked before it is mature. An immatme kernel has not had time to store up all the food it wanted, and consequently will be more or less weak in vitality. Early picked corn, if well preserved, may germinate well under farorable conditions, but its constitution has been weakened, and the yield will be 
correspondingly lessened. Nature should be allowed to ripen the seed in her own way.

"Selecting seed corn from the crib is alway's objectionable. The ritality has generally been more or less irjured, and, while the ears selected may have a good appearance, one can tell nothing as to the character of the stalks which produced them. Numerous experiments have shown that crib corn produces smaller yields than corn that has been properly selected in the field and well preserved through the winter.

"The quality of seed corn selected from the field should always be considerably more than will be needed for planting, so thit there may be room for further and more critical selection later on. If the quality of seed ears selected before the general husking is insufficient, it is a good plan to have a small box attacherl to the outside of the wagon box into which desirable seed ears found while husking can be put."

When you buy seed corn, get it on the ear and from a place in your same latitude, and an early variety.

All seed corn should be tested before planting. The importance of this is seen when we consider that generally farmers do not get more than an average of 75 per cent. of a stand of corn, when the average shomld not be less than 95 per cent. After corn has once been planted it is generally too late to replant the entire field if the stand is poor, and I have never known replanted corn in missing hills to make any thing more than fodder.

The method of testing seed as given by the Purdue Lniversity Agricultural Experiment Station is as follows:

"There are many simple methods of making the germination test, but in all cases each ear should be tested by itself. Experiments have shown that as a rule the testing of a few kernels picked at random from different parts of the ear will safely determine whether or not the ear should be used for seed. About five kernels should 


\section{KING CORN}

be taken from each ear and kept separate, and the ear from which they came must be marked in such a way that it can be readily located after the test is made. In selecting the kernels for the test, take one from near the butt, three from various parts of the middle portion, and one from near the tip. Look for elevated or swollen spots on the ear from which to take the kernels. If there are any weak germs, they are likely to be found on the swollen spots, because there the cob was probably more or less spongy and retained moisture after the rest of the ear was dry and out of danger of being injured.

"The requisites for germination are moisture, warmth and air. Any chamber or vessel in which these can be provided will answer the purpose. The exact method employed will be largely a matter of convenience. An ordinary dinner plate with a double fold of moistened muslin between which the kernels can be laid, covered with another plate to prevent too rapid drying, makes a very good germinating chamber. A shallow box into which several lots of kernels may be laid between folds of moistened paper and covered with a lid will do. A shallow box containing moist earth or sawdust in which the kernels may be planted may also be handy. In any case the tester should be put in a warm place, but not too near the stove. The temperature of the ordinary living room is about right, provided that it does not become colder than 55 degrees during the night.'

After seed has been properly saved and tested, and having your soil built up in the manner I have detailed in previous chapters, the next important step is the preparation of the seed bed.

In a previous chapter I showed the importance of breaking wp the suil at the right time, and assmming that that is done properly, the same should be worked down to as nearly level as possible immediately after plowing. The best plan is to run over each half-day's plowing with some good pulverizer. A level, well-pulverized surface 
absorbs lueat and retains moisture, botin essential to good corn growth.

1 pulverizer should be wed that will pulverize the soil to a depth of at least three inches.

Where soil is dry at plowing time, or where a heary coating of green crops or oryanic mater has been plowed under, I would advise the use of a roller or dray before using a pulverizer. No time is lost by rumning the pulverizer over your fields in opposite directions. IV all hurry tou much in preparing the seed bed. If we wamld rum the pulverizer over our fields a dozen times, or for a week before planting, it would more than pay us for the time spent. ( )ur soil would be level, mellow and in wond tilth. The planter could be run with ease and at a nni. form depth, and the seed would be placed in a bed of warm, moist earth, surrounded by every condition condexcive to quick, healthy growth, thus securing a better stand of corn. The wrowth of weeds would be so checked that the corn would have a chance to reach the cultivating stage before they were of any size.

Having the seed bed in proper condition, the next important step is planting. In the main part of the corn belt the best time to plant is between the ist and roth of May. As a rule, planting cannot be done with safety before May I unless the spring is early and the soil is in excellent condition as to dryness and warmth. In the south part of the corn belt planting may be earlier. It is not infrequently the case that good seed will fail to grow when planted too early or when the soil is too moist and cold. Heat, air and moisture cause the growth of seeds, and the seeds must have just the right proportion of each; too much of either one is injurious to the plant.

The earth should be pressed firmly over the seed, which causes the moisture to come in contact with the outer covering of the seed and produces a sufficient amount of heat by preventing air circulating too freely 
around the seed. The seed placed in the soil under favorable conditions commences to grow at once.

Again, corn should not be planted too deeply.

In my long experience in growing sweet corn I have learned that two-thirds of the poor stands may be attributed entirely to too deep planting. I make it a rule to plant not over one inch in depth, and when seed is good always get 95 per cent. and over of a stand. Planted five inches in depth, the seed will not germinate 5 per cent. The same is true as to field corn. A covering of one inch is sufficient. Covered three inches or more. growth is wnhealthy and not rapid.

Corn has two sets of roots, one above the surface and the other underground. The ones above the surface are the brace roots, and do nct perform their functions until the plant is of considerable size, generally not until the corn is laid by. These roots are important to corn growth, because they push out and penetrate deeply int, the ground at a time when the corn plant is bearing its harvest and needs to be supported from the onslaught of winds and storms.

These brace roots shoot out from the plant above its first joint, about an inch above the grain. Plant the grain too deep, a new and unnatural joint must be formed at the surface (it is never formed under the surface), from which the brace roots begin to grow. This new joint-forming process stays the growth of the plant until the new joint is formed.

Heretofore I have tried to impress upon my readers the fact that we should study nature's ways of doing things, so that we may avoid doing that which crosses her, for if we do we pay the penalty.

A study of corn growth will convince any student of nature that corn is injured when its seed is planted to a greater depth than one inch. If this be true, then the practice of planting corn in a furrow and filling the furrow by cultivation is wrong. 
Next to planting the corn the proper depth is a good corn planter with which to plant the seed.

A poor corn planter is about the worst nuisance on the farm. Get the best that can be procured, and consign all poor ones to the scrap heap.

In selecting seed corn discard tips and butts and run seed through a grader so same is of uniform size before using in planter. The planter should be set for planting two grains to the hill.

Extra strong soil will mature three grains to the hill, but under all conditions I have found that it is best to only plant two grains to the hill; but in planting two grains to the hill it is very important that you have good seed or your stand may be poor.

Between planting and cultivating there elapses generally two weeks. Sometimes, on acconnt of rains, this time may be extended, especially if our soils are naturally wet and not well drained. When it is possible to work the soil we should not be idle during this time. We must not forget that a crust on the soil causes the soil moisture to evaporate very rapidly. A loose soil prevents this and absorbs moisture from the air.

An insufficient quantity of available moisture is a great cause for short crops, hence the importance of doing that which will conserve the moisture so the corn roots will absorb it.

Nothing conserves moisture in the soil like a soil mulch. This soil mulch is the great secret of corn cultivation. A large crop of corn cannot be grown without it, so the necessity of beginning to create soil mulch in the earlier stage of corn growing, or between planting and cultivating time. It will practically stop all moisture evaporation from the surface of the soil, and stirring the soil will kill the weerls, so to procure this soil mulch the harrow or pulverizer should be run over the planted corn before the corn sprout has pushed its way through the soil. 


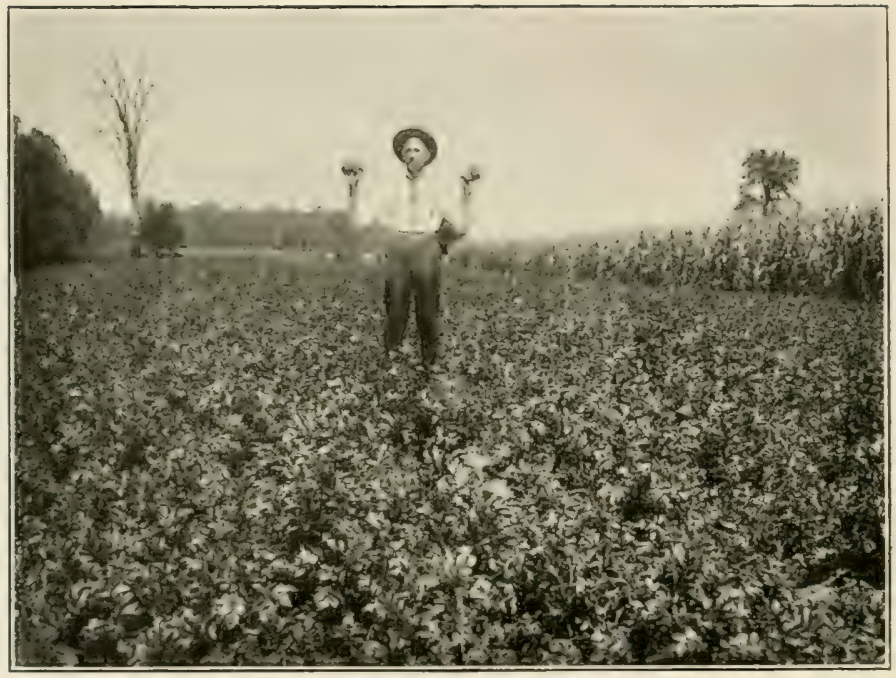

A Promising Potato Field.

Picture taken September 11, 1909. This field was fertilized by plowing under heary crop of Vetch; it yielded 250 bushels per acre of large, fine potatoes. 


\section{CHAPTER XIII.}

\section{The Culture of Corn.}

Corn can only reach its highest stage of development when it is properly cultivated. The corn root is the mouth of the corn plant, as its food is collected from the soil and fed to it thromgh its routs. hence the necessity of protecting the corn reots and putting about them the enrironments essential to their best development and growth.

The corn roots must be protected so they can perform their functions of collecting plant food undisturbed.

Any method of cultivation that destroys any portion of the corn roots is disastrous to the corn plant, and reduces the yield in proportion to the amount of roots destroyed.

Eminent professors of corn culture have by experiments proven that corn routs pruned to the depth of three inches, six inches from the hill cut the yield six bushels to the acre, and four inches deep. eighteen bushels to the acre.

Cultivating deep and tearing off the corn roots after the second cultivating will decrease the yield from three to twenty bushels to the acre, so any method of corn cultivation that destroys the roots must be abandoned if we would secure the highest and best yield.

As to the two first cultivations, corn may be cultivated deeply, but after that the cultivation should not exceed one or two inches in depth.

Corn roots must have plenty of moisture, and they seek this moisture near the surface. During the growing sea- 


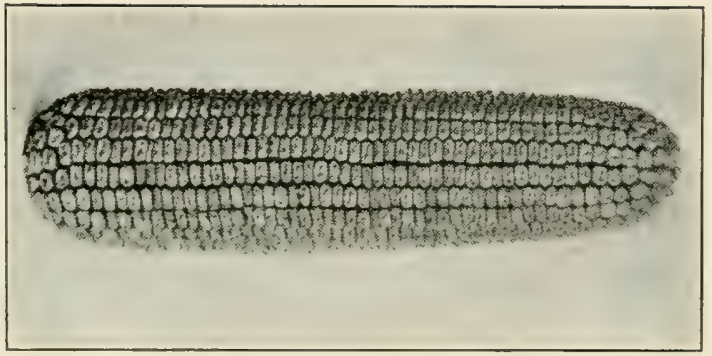

1909 Champion Ear of Corn, an almost Perfect ear. 


\section{THE CULTURE OF CORN}

son the corn plant will absorb its own weight of water over and over again, and as this water passes throngh the corn system the corn food is carried into the cells of the leaves, where the sunlight transforms it into the material that the plant needs in its growth.

It is said that the leaves of the corn plant on an acre of soil will throw off during a season water that would cover the ground to a depth of ten inches.

This, if true, would prove that we must conserve the soil moisture if we successfully grow corn. This is the most important feature of corn culture, and one we must learn and appreciate.

That system of corn culture must be adopted which will conserve the soil moisture so that it may be arailable in sufficient quantities during each day of the growth of the corn plant. The moisture must not be allowed to evaporate from the ground.

The only way to preserve soil moisture and prevent evaporation is to keep stirring the ground to the depth of one or two inches, so as to procure the soil mulch or blanket of finely pulverized soil on top of the ground. We must ever keep in mind that corn has but two sets of roots, feeding and bracing. The feeding roots are small and tender, and run out from the plant in a horizontal direction and when full srown exceed the height of the stalk. They first appear but a few inches below the surface and never penetrate to the depth at which the soil was broken until the corn is in silk. An examination of the field during the growing season from the second cultivation to the "laying-by" time will show these feeding roots occupying the entire soil between the rows of corn.

When the corn reaches its silking stage these roots will appear in great quantities. They are searching for food and moisture to complete the growth of the corn plant; hence the necessity of their protection and conserving the moisture for their use.

No weeds must be allowed to grow, as they rob the 


\section{THE CULTURE OF' CORN}

corn roots of food and moisture needed for the corn plant. Cultivation must be kept 11 ) as long as possible, so that the soil moisture may be maintained until the corn plant has stored sufficient food to mature its ears of corn.

My most successful method of corn culture is to first plow the corn each way, as deep as possible, when the corn is large encugh, getting as close to the corn as possible. All cultivation after this must be such as stir the soil to the depth of an inch, the cultivation to be frequent and kept up until the corn is well along towards maturity. When corn is too large to cultivate with two-horse cultivators a one-horse cultivator that barely scratches the soil should be frequently used.

Good corn culture means an early starting and a late discontinuance of the cultivators.

I have known corn yields to be cut short by lack of early and late cultivation. When the growth of corn has been once stmuted the damage done cannot be repaired.

I once gave one-half of a field of corn two late cultivations with a one-horse combined harrow and cultivator, and increased the yield nearly ten bushels per acre over the half not cultivated.

The corn's crisis is when it has completed its stalk growth and hegins making the ear. If at this time the dry season begins and soil becomes so compact and dry that moisture and air is excluded, conditions favorable to the proper maturity of the ear are cut short. At this critical time the cultivators should be kept moving. 


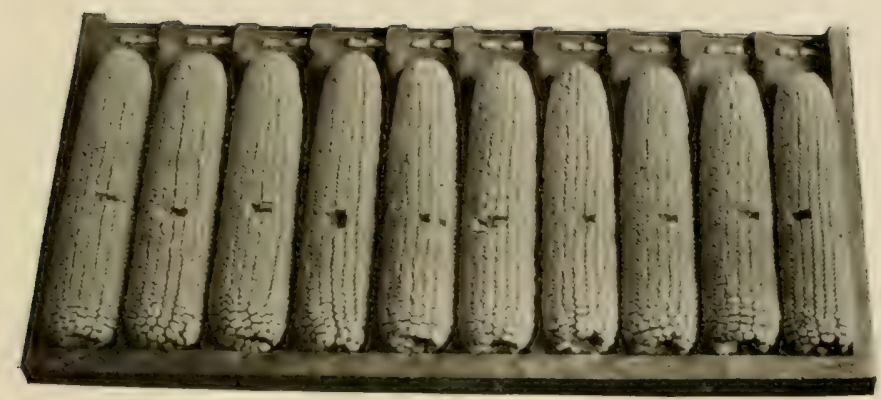

1909 Champion Ears of Corn. As Near Perfect as Corn can be produced. 



\section{CHAPTER XIV.}

\section{Sweet Corn.}

Sweet corn is used almost entirely for human food. so vast quantities of it are consumed upon our dining tables.

A favorite way of cooking it is to boil it on the colb. and served in this manner it is regarded as one of the "courses of the most refined and epicurean dishes."

The great canning industry of the Lnited states also consume great fuantities of it, their average yearly pack being over six million cases, of two dozen cans each.

The sweet corn plant cut up and properly cured for fodder makes a valuable feed for all stock, one of the most valuable that can be grown on the farm.

Stock will entirely consume it. As a winter feed for horses it excells in value any feed grown.

It puts and keeps horses in good condition. It cannot be over-fed, and horses and cattle will almost entirely subsist upon it through the winter season, coming ont in the spring in fine condition.

It is one of the best milk-producing feeds grown, producing quantities of well-tasting rich milk. Where dairying is carried on to a large extent sweet corn fodder is considered worth ten dollars per acre. And it is worth this sum for general feeding. Some even claim that one acre is equal to eight acres of grass, and worth more than two acres of any forage crop grown.

Sweet corn fodder should be cut when the leaves are glazing and put in small shocks for curing. 
In habit of growth sweet corn is smaller than field corn, but otherwise its characteristics are similar.

It requires the same soil, attention and cultivation to grow it as field corn.

Like field corn, its varieties are many. The varieties chiefly grown for canning purposes are Stowell's Evergreen, Early Evergreen, Crosby's Early and Country Gentlemen, the first and last named being the leaders.

While Stowell's Evergreen has large ears, it is the sweetest and most valuable of all. The author's larye and long experience with it for canning purposes has convinced him that this variety wathered in the risht stage comes nearer filling the reguirements for a perfect sweet corn than any variety that is grown.

While it is true that the Country Gentlemen variety has the reputation and sells for the most money, yet Stowell's Evergreen plucked at the right stage has a flavor that cannot be excelled.

In the main sweet corn belt it can be planted from May I to July I.

Planting in wet, cold soils must be avoided, as the seed will rot.

The planting of the seed should never exceed an inch in depth.

As I stated in the previous chapter, a poor stand of sweet corn can be attributed nine times ont of ten to too deep planting of the seed.

The seed must have just the right amount of heat and moisture to germinate it properly, yet there is no difficulty in securing a stand if one is careful in planting it when ground is warm and not too wet.

There seems to be a disposition to plant sweet corn too thick. This is a mistake. There should never be to exceed three grains to the hill, and when drilled set drill to drop about one foot apart.

Good seed ought to test 95 per cent; where it tests less than this I would advise hand picking the seed, picking 


\section{SWEE'I CORN}

wt the brightest and best grains. It pays to do this, and it can be done in bad days of spring when wher work cannot be done.

Canning factories pay from five to ten dollars per ton fur sweet corn jerled from the stalk, and delivered to the factory in a green stage fit for canning.

Some factories have a system of grading or testing by which a bushel is taken from each load and shucked and weighed, when it must come up to a certain fixed standard, but generally it is bought by the ton just as it is jerked in the field. The ten-dollar price is paid for the smaller eared variety like Country (ientleman, which do not produce a large number of tons per acre.

The highest price paid for heary yielding varieties, like Stowell's Evergreen, is eight dollars per ton, and at this price there is money in growing it, as it will produce from four to six tons per acre, to which add the value of the forlder and you have one of the most profitable crops grown on the farm.

If it does not prove a profitable crop it is because it has been planted on pour soil or its cultivation has been neslected.

It will respond and produce fine paying crops if wiven a chance.

I have known farmers to put it on their poorest, worst drained soil, give it practicaly no cultivation and then curse and condemn it as a non-money maker.

I knew one farmer who planted five acres and never cultivated it once, and then he expressed himself that there was no money in growing it.

Sweet corn to be fit for eating or canning must be harrested when the shucks are green and while the grain is in the milky stage. It is of no value for eating or canning when the shuck is yellow and the grain is hard. It must be bronght to the factory the day harvested. If allowed to stand in the wagon over night it heats and becomes valueless. While it is true that factories hold it over the 


\section{SWEET CORN}

night, yet they put it on cement or ventilated floors, where it is spread out thin so that air reaches into the interior of the pile and where there is no danger of its heating.

Sweet corn has but one enemy, the worm found in the end of the ear at certain seasons of the year, and which is said to be the same worm that destroys the cotton crop. the Bollworm.

While this worm is found to some extent in all sweet corn it is chiefly found in sweet corn grown in warmer latitude. For this reason sweet corn grown south of a line parallel with the Ohio river cannot be grown for or handled by canning factories with profit, as the work of removing the corn damaged by the worm adds too much expense to the finished product.

In the sweet corn growing section this worm appears late in the season, but it has been known to make its appearance before the season was more than one-half past, and to put a complete stop to further operations of factories.

It always appears to a considerable extent in late planting. For that reason sweet corn for canning purposes should never be planted later than June I5 to 20.

No remedy has yet been discovered by which this worm or its parent can be destroyed.

The chief sweet corn growing States for canning purposes are Illinois, Iowa, Maine, Ohio, New York, Maryland. Wisconsin and Indiana.

The States are named in the order as to quantity produced for canning.

While Maine has the reputation of packing the best corn, yet all the other states mentioned can and do pack just as good corn as Maine.

The canning of sweet corn so as to be palatable is an art in which but few are skilled. The best of sweet corn can be spoiled in canning. Like the preparation of any 
food, so as to be a delight to the taste, it is wenerally up to the cook.

Sweet corn to be good must be sweet, and this sweetness cannot be artificially supplied by the addition of sugar, for the original sweetness cannot be imitated.

No Northern State has any alvantage wer another as to possessing a soil or climate that will produce sweet corn containing an abundance of natural sweet, for Southern States will grow sweeter sweet corn than any Northern State. It is a fact, however, that sweet corn grown on sandy soil will contain more sugar than that grown on muck or heavy black soils.

If Maine packs better corn it is becanse she has better cooks in her canning factories, and possesses more skill in knowing how to handle the raw material so as to prevent it from deteriorating before it gets into the can.

Sugar begins to disappear from sweet corn as som as the ear is separated from the stalk.

A chemical change sets about at once and the stoar is transformed into other stubstances. The rapidity of this changing process can be arrested to a certain extent only by handling the corn (puickly and keeping it at as low a temperature as possible.

A large body of plucked sweet corn will heat very quickly and become worthless, because the chemical change brought about by the heating destroys the sugar in the corn.

If any Northern section of the country has any advantage over another it is because it has such a low temperature that the corn can be kept in a tencler and cool stage for a longer period of time.

An excessive rainfall is injurious to sweet corn. During a dry seasnn if a healtly wrowth can be maintained the product will contain more sugar.

By proper cultivation during dry weather a healthy growth can be maintained and a large growth of corn can be produced. 
I have demonstrated this during the last two seasons to my complete satisfaction. The season of 1908 was very dry, and my crop of sweet corn was the best quality and the best yield I ever produced. The reason of Igog was too wet, and my crop did not come up to quantity produced to the acre by a ton or more, and the quality was not as good.

When the skin of the grains of sweet corn is broken it mulergoes fermentative changes at a rapicl rate becanse of its high per centage of sugar, and this also affords an opportunity for dangerous bacteria to enter into the corn juices, resulting in sour corn, the canners' worst enemy.

No amount of heat that can be applied by canning apparatus will destroy them.

It is said that the source of the germ of these bacteria is from the ears of corn, their presence being found on the kernels beneath the husks.

All this shows the necessity of great care in getting sweet corn into the factory in the right stage, condition and manner and the proper handling of it in the factory.

Sweet corn has a low conducting power of heat, hence the necessity of a long period of heating in order that bacteria that produce spoilation be killed.

If not sufficiently heated the center of the can is not sterelized and souring begins there.

The reason the housewife does not successfully can sweet corn is because she does not submit it to a proper heating process. If she would boil it seven hours in a kettle it probably would keep for her.

A woman once asked the writer the name of the acid he used in his canning factory to preserve sweet corn in the can from spoiling, and when she was informed that no acid was used, but that the preserving process was obtained solely by sterilization or heat, sle was incredulous and went away firmly believing that the writer was lying. 


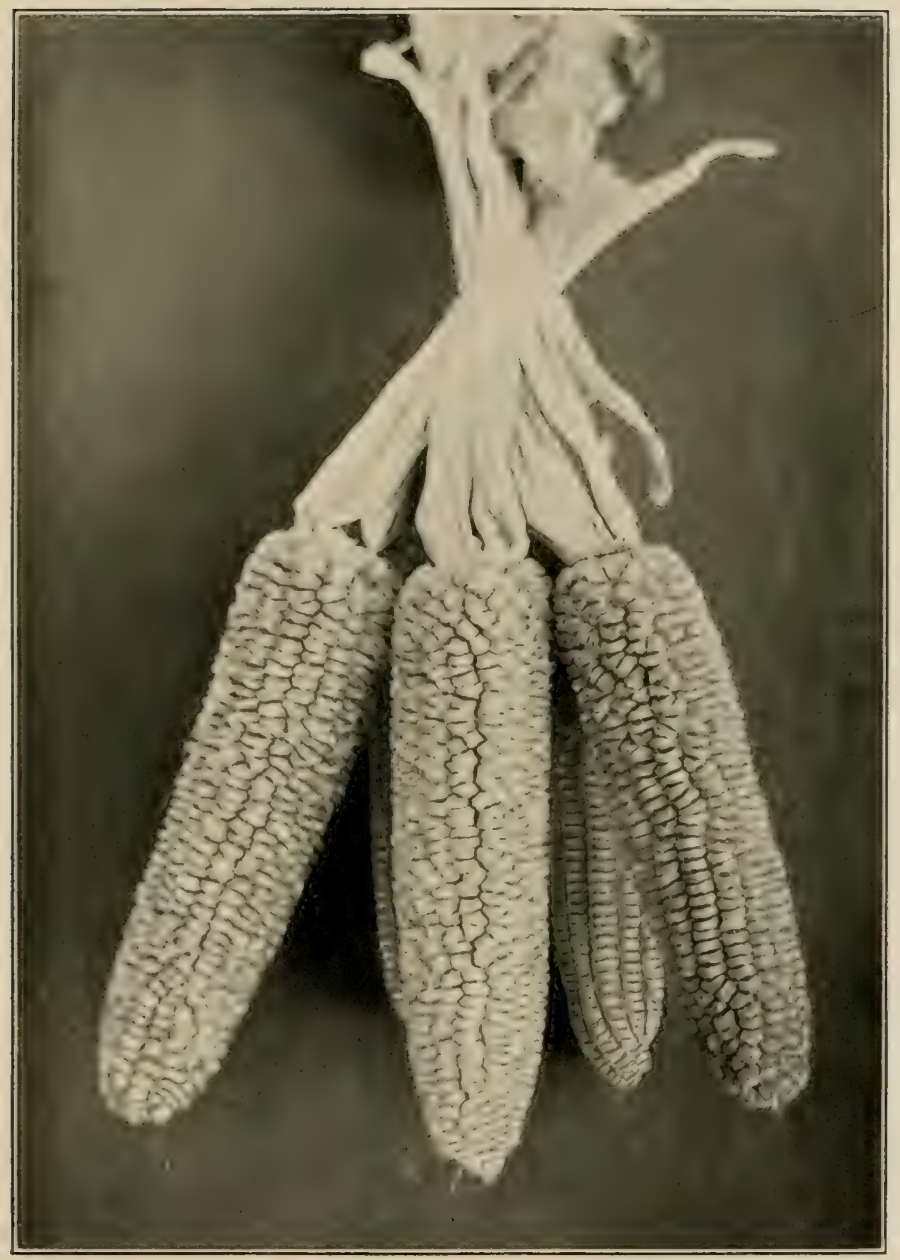

A Good Type of Sweet Corn Seed, Stowell's Evergreen. 



\section{CHAPTER XV.}

\section{A Chapter of Don't Forgets.}

DON'T FORGET - That soil is as jealous as a lover; neglect or mistreat it and its bonnty is withdrawn. Caress and feed it, it yields a hundredfold.

DON'T FORGET - That a farmer becomes a soil robber when he does not each year put back into the soil more organic matter than he farmed out of it.

DON"T FORGET-That the corn stalk is one of the farmer's best by-products. A ton of them contains sixteen pounds of nitrogen and nearly as many pounds of potash, and the organic matter in them is of inestimable value for supplying humus to the soil.

DON'T FORGET - That the moisture conserving capacity of the soil is increased by the plowing under of large amounts of organic matter.

DON'T FORGET - That organic matter in the soil aids soil ventilation, and furnishes supplies of nitrogen for the growing plant.

DON'T FORGET-That rye, hungarian and the legumes are the best producers of organic matter.

DON'T FORGET - That the farmer who refuses to supply the wants of his soil is traveling along the highway of the abandoned farm.

DON'T FORGET - That it takes less than fifty years to farm out the fertility of the soil if none is added in the meantime.

DON'T FORGET - That England's soil, after a tillage 


\section{A CHAPTER OF DON'T FORGETS}

of centuries, is as fertile to-day as in any stage of its existence, kept so by sane methods of soil building.

DON"T FORGET-That the entire prosperity of our conntry is founded on the fertility of ont soil, and that he only is a patriot who lends his aid to conserve that fertility.

DON'T FORGET-That the conservation of soil wealth means a full dimner pail in the hands of every working man, a loaf of bread on every dining-table and comfortable clothing on every human body.

DON"T FORGET-That the conservation and increasing of soil fertility means the building up of an empire in our Middle ITest, richer in power and splendor than any ever dreamed or imagined.

DON"T FORGET-That environment and greed lias made us soil robbers, that we must get away from that environment and greed or perish.

DON"T FORGET-That he who sets closest to the soil reaps its richest reward.

I)ON"T FORGET-That he only is a farmer who loves and feeds his soil.

DON"T F()RGET-That the proper feeding of the soil requires the exercise of a fertile brain.

DON"T FORGET-That a farmer who does not love his soil will mistreat it.

Dr N"T F( )R(iET-That a soil robber is always a man of greed.

DON"T FORGET-That soil-building is but the application of simple common sense to the solution of simple agricultural problems.

DON"T FORGET_That no one is worthy the name of farmer muless he is willing to do that which will give his soil a chance to do its best.

DON'T FORGET-That for soil to do its best it must be fed the food elements it needs.

DONT FORGET-That the soil robber is the highwayman of agriculture. 


\section{A CHAPTER OF DON'T FORGETS}

DONT FORGET - That crop rotation alone will not build up your soil.

DON'T FORGET - That you cannot wet too much organic matter in your soil.

DON"T FORGET--That the farmer should be trained for his work as the lawyer is trained for his profession.

DON'T FORGET-That he who expects to build "1p his soil by crop rotation alone is doomed to failure and bitter disappointment.

DON'T FORGET-That it requires as much intelligence to direct the business of building up the soil as it does to direct the affairs of trade or commerce.

DON"T FORGET-That the more intelligence you put into your soil the more money value you will extract from it.

DON'T FORGFT-That farm values are based on soil fertility.

DONT FORGET-That the soil, like the horse, gives its best service when it is well groomed and fed.

D()NT FORGET-That he gets closest to the soil who studies its whims, its moods and its needs.

DON'T FORGET-That soil building is the most vital problem of the age.

DONT FORGET-That you increase the value of your soil in proportion to what you feed it.

DON'T FORGET-That skilled workmen are required in all trades, why not on the farm?

DON'T FORGET-That our entire substance comes from the soil. If it fails us, we perish.

DON"T FORGET-That the American farmer has yet to learn the lesson of "proper feeding of the soil."

DON'T FORGE'T-That soil is as sensitive and resentive of neglect as a human being.

DON'T FORGET - That in the history of nations no crisis ever came but what God produced the man to handle it, so in the crisis of soil exhaustion God has produced the plant or material that will restore it. 


\section{A CHAPTER OF DON'T FORGETS}

DON'T FORGET - That you cannot get anything out of wornout soil until you put something in it.

DON'T FORGET - That you must forget the way the pioneer farmed. You must think only of the way the soil must be farmed to-day.

DON'T FORGET-That the purpose of this book is not so much to tell people exactly how to enrich the soil, as it is to, rightly direct their thoughts and investigations that they may help themselves to solve the soil problem.

DON'T FORGET-That your severest test is in getting your wornout soil started towards increasing fertility.

DON'T FORGET-That in pushing along the wornout soil towards fertility, it's the keeping at it that furnishes the momentum that accomplishes results.

DON'T FORGET - That it is said that the net income of the average farmer is greater than the net income of the average city man, but that average cannot be maintained without increasing the fertility of the soil.

1)(NT F()RGET-That much of soil-building is being done like he who is trying to pull a two-horse load with one horse hitched to the end of the tongue.

DON'T FORGET - That you cannot build up your soil as long as you continue to carry to the barn everything that grows upon it.

DON'T FORGET-That covering the soil with green crops is one of the farmer's best methods of soil-building.

DON'T FORGET - That organic matter gone up into smoke leaves no residue of value to the soil.

DON'T FORGE'T-That corp rotation is a gay deceiver.

DON'T FORGET - That it has been said that the soil is a living thing. The better reason why it should be fed.

DON'T FORGET-That prosperous looking farms and farm buildings are but the reflex of a fertile soil.

DON'T FORGET-That the man behind the plow is 
no longer a force in a community when his plow is turning infertile or wornout soil.

DON'T FORGET - That it is folly to select and plant good seed in soil too poor to grow and mature them to a paying crop.

DON"T FORGET-That the legme crops furnish the "balanced ration" needed for soils.

DON'T FORGET - That a breathing soil means a living, fruitful crop. That soil cannot breath unless it is ditched and full of organic matter.

DON'T FORGET-That the ratio of increase of your soil will be in proportion to your interest in scientific farming.

DCNT FORGET-That the great secret of soil restoration is to keep your soil busy growing crops for both harvesting and plowing under.

DONT FORGET-That the soil that produces the poorest crops is like an inferior farm product-it doesn't bring the price.

DON'T FORGET-That improved agriculture is brought about by fertile brains as well as fertile fields.

DON'T FoRGET - That when nature built the original soil she used a lavish supply of organic matter in its construction.

DON'T FORGET - That to pull every day a full twohorse load requires two horses well fed and groomed. To make the soil pull its load of good crops it must be fed and groomed each day.

DON'T FORGET - That the real farmer is one who manages so as to put back each year into the soil more fertility than was extracted from it by growing crops.

DON'T FORGET-That the bedrock of the paying farm is soil, well fed.

DON'T FORGET-That your success in soil restoration depends on your gumption to catch onto nature's ways of soil-building.

DON'T FORGET-That the farmer who has no 


\section{A CHAPTER OF DON'T FORGETS}

thought beyond the year's profit. has his soil headed towards the doom of soil exhaustion.

DON'T FORGET - That the men who once grew big crops on our wornout soils were poor farmers or else these soils would now be rich in fertility.

DON'T FORGET-That the policy of properly feeding the soil is not only good for future generations, but for the farmer who practices it.

DON'T FORGET-That the farmer who does not ever have in view the conservation and increasing of soil fertility is obstructing his own way to success.

DON'T FORGET-That he who produces the best crops is the one who ditches and feeds his soil the best.

DON'T FORGET - That the farmer who says he cannot afford to plow under green crops, will soon say there is no money in farming.

DON'T FORGET-That there is no limit to the possibilities of our well-drained soils so long as we do not limit their feed of organic matter.

DON'T FORGET-That you cannot overfeed your soil with organic matter.

DON'T FORGET-That the truly successful soilbuilder is the one who drains his soil, tills it well, feeds it large quantities of organic matter and keeps it busy with growing crops.

DONT FORGET-That the physical condition and available plant food of the soil can only be maintained by feeding it with plenty of animal and regetable matter.

DON'T FORGET-That the fonndation of soil-building is draining.

DON'T FORGET - That draining a soil is like currying a horse - it opens the pores and increases circulation.

DON'T FORGET - That organic matter is farmed out of the soil in less than four years; hence the necessity of adding to the supply each year.

DON'T FORGET-That well-drained soil full of organic matter is never sour. 
A CHAPTER OF DON'T FORGETS

DON'T FORGET - That it is the folly of follies to use commercial fertilizer on soils lacking in organic matter.

DONT FORGET-That it takes as much plant food to grow weeds as corn; kill the weeds.

DON"T FORGET - That the boy and the virl are two of the best products of the farmer. if trained along the lines of scientific agriculture and farm domestic science. 


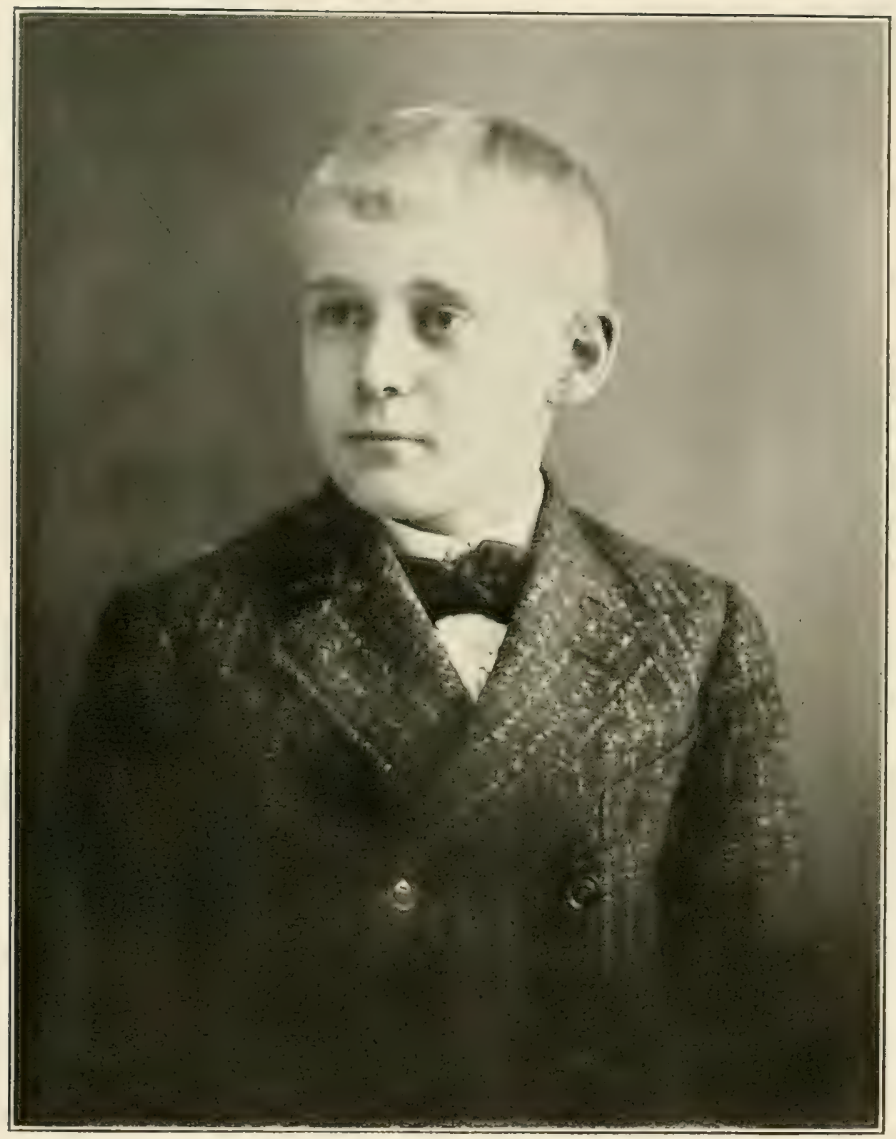

The farmer's best product, if educated along the lines of scientific agriculture. 


\section{CHAPTER XVI.}

\section{Conclusion.}

If in the pernsal of the preceding chapters the reader has imbibed some of the author's enthusiasm for soilbuilding, crop-growing and love of nature, then the mission of this book has born good fruit.

There is no grander nor more useful study than the study of the soil problem. It is a study that is of more vital interest to the public than any other, for the very fabric of life depends upon its correct solution.

Since penning the proem and introduction of this book a mighty agitation has swept orer and into every part of our country regarding the high price of living.

The price of farm products and manufactured goods being higher than known for years, our people are engaged in a great discussion trying to ascertain the canse of these high prices.

The consensus of opinion seems to be that the chief cause of high prices is the fact that too many of our people have left the farms for our cities, so the cry has gone up that the only solution of the question of high prices is "more producers and less consumers." "Back to the Farm" is the slogan.

Our educational system is faulty. The boy and the girl have been educated away from the lines of agriculture and farm domestic science.

The ambitious country boy with bright, sharp intellect has had held up to him only the ideals of business and 


\section{CONCLUSION}

professional life. The soil problems, the love of nature, the joy and financial returns of farming fertile fields and the peacefulness of good farm surroundings have had no place in his education, so he has grown up beliering that no true happiness or financial gain is to be found on the farm.

The farmer boy so educated has drifted into the neverending strife and worry of city men and business, and our farms have lost the best bloom of our young manhood.

True, some of the boys have attained success and eminence, and maybe happlness, but the rast majority of the mighty army of boys who have drifted from the farm into the cities bear the marks of disappointment and blasted lives; they have not gotten out of life what they would have wotten had they been educated along the lines of scientific agriculture and remained on the farm.

While we are changing our methods of farming, so as to build up our soils, let us so change our educational system that it will educate our boys and girls to live rural lives and help to solve the problem of the soil and of farm domestic science, that the fields of our farms will be made richer, our herds and flocks be built up of better grades, our homes inside and out be made more pleasant and more attractive.

When this is done the great procession of boys and girls will be headed towards the farm, and the professions. the mercantile and manufacturing business will be relieved of the congestion of workers.

Nearly forty years ago the anthor, a boy of fifteen, bid an affectionate adieu to his mother on the old farm porch and set his face towards the city and entered its busy activities. He engaged in mercantile pursuits for a time, attending schol and college, educated himself for the profession of law, engaged in the sucessful practice of his profession for many years, engaged in manufacturing. farming. political strife and office holding, and now finds 


\section{CONCLUSION}

himself past the meridian of life with a sreat fund of experience to his credit.

lint now as the border land of eternity appears to view. realizing that it will be but a short time nutil "life's fitful dream" will be oer, he yearns to spend the remainder of his days upon the farm, that he may rewain some of the lost pleasures of farm life. [ joun the farm, where far removed from the bitter, galling strife of men, he may commune with nature, study soil problems, smell the bloom of vetch and clover, admire the beanty of wrowing plants. hear the songs of bircls and the soothing rustle of the corn, and hask in the delights of sunshine and open sky.

Farmers of America, you do not realize what God and Nature have done for your. Your lines have indeed "fallen in pleasant places," hut oh, so many of you have failed to grasp your opportunities. Ye are forl's chosen people and yet you do not act it.

If you are tempted to leave the farm, command the tempter to get behind you. Stay with your fields, your flocks and herds, improve your surroundings and make them more attractive; train your boys and girls to be woud farmers and housekeepers and enjoy the peaceful, restful life of the farm.

There's music in the words, "Back to the Farm," but there is sweeter music in the words, "Better Stay on the Farm a While Longer."

"The farm is the safest and surest.

The orchards are loaded to-day;

You're as free as the air of the mountains.

And monarch of all you survey.

Better stay on the farm a while longer.

Tho' the profits come in rather slow;

Remember you've nothing to risk, boys,

Don't be in a hurry to go." 





One copy del. to Cat. Div. thati 21 s9:0 


\section{Lbearar ore Whin or conceness

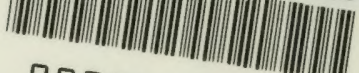 00009354578}

